\title{
CASE STUDY ON ENHANCED LANDFILL MINING AT MONT-SAINT- GUIBERT LANDFILL IN BELGIUM: MECHANICAL PROCESSING, PHYSICO-CHEMICAL AND MINERALOGICAL CHARACTERISATION OF FINE FRACTIONS <4.5 MM
}

\author{
Daniel Vollprecht ${ }^{1, \star}$, Juan Carlos Hernández Parrodi ${ }^{1,2}$, Hugo Lucas ${ }^{3}$ and Roland \\ Pomberger ${ }^{1}$
}

\author{
${ }^{1}$ Montanuniversität Leoben, Department of Environmental and Energy Process Engineering, 8700 Leoben, Austria \\ ${ }^{2}$ Renewi Belgium SA/NV, NEW-MINE project, 3920 Lommel, Belgium \\ ${ }^{3}$ RWTH Aachen University, IME Process Metallurgy and Metal Recycling, 52056 Aachen, Germany
}
Article Info:
Received:
5 January 2020
Revised:
24 February 2020
Accepted:
25 February 2020
Available online:
31 March 2020
Keywords:
Enhanced landfill mining
Fine fractions
Mechanical processing
Chemical composition
Mineralogical composition
Waste-to-material

\begin{abstract}
Fine fractions obtained by mechanical processing of excavated waste constitute a challenge for (enhanced) landfill mining projects. These fractions are mainly composed of humified organic and weathered inorganic compounds, whereas metals and calorific fractions are depleted. In this study we present data on the chemical composition and grain size distribution of the fine fractions $<4.5 \mathrm{~mm}$, as well as on the mineralogical composition of the two finest subfractions $(0.18$ to $0.5 \mathrm{~mm}$ and $<0.18 \mathrm{~mm}$ ). Chemical analyses indicate no trend regarding the enrichment or depletion of heavy metals in the different particle size ranges. Leaching from the finer fractions is somewhat higher than from the coarser fractions (i.e. 1.6 to $4.5 \mathrm{~mm}$ and 0.5 to $1.6 \mathrm{~mm}$ ), although the fraction 0.18 to $0.5 \mathrm{~mm}$ shows the lowest overall leaching. Pseudo-total contents of $\mathrm{Cu}, \mathrm{Zn}, \mathrm{Cd}, \mathrm{Hg}$ and $\mathrm{Pb}$ and leachable contents of $\mathrm{Ni}$ exceed Austrian limit values for the production of soil substitutes from wastes. Electron microprobe analyses indicate that $\mathrm{Zn}$ and $\mathrm{Pb}$, which exceed limit values for pseudo-total content, are present as Fe- $\mathrm{Zn}$ alloy, $\mathrm{ZnS}$ and $\mathrm{ZnSO}_{4}$, and metallic $\mathrm{Pb}$ and $\mathrm{Pb}$-Ca phosphate, respectively. In summary, dry-mechanical processing, which is a feasible method in the particle size range $>4.5 \mathrm{~mm}$, showed a limited effect in the range $<4.5 \mathrm{~mm}$. Removal of $\mathrm{Pb}$ - and $\mathrm{Zn}$-containing phases is highly challenging due to the diverse mineralogy and fine grain size of few $\mu \mathrm{m}$. Consequently, it seems unlikely that the Austrian limit values for soil substitutes can be met.
\end{abstract}

\section{INTRODUCTION}

Landfill mining, "a process for extracting [...] resources from waste materials that have previously been disposed of [...]" (Krook et al., 2012) was introduced in 1953 (Savage et al., 1993), whilst interest in this topic has increased significantly over the last 30 years. Although from an economic perspective landfill mining is largely not a feasible option (Laner et al., 2019), a combination of the process with environmental remediation may be promising (Frändgård et al., 2015), particularly when considering the value of ecosystem revitalisation (Bulakovs et al., 2017).

Fine fractions produced by mechanical processing of landfill mining materials are a major obstacle for an economically feasible (enhanced) landfill mining ((E)LFM) due to the predominant amounts and problematic characteristics (García López, et al., 2019; Hernández Parrodi, et al., 2019b; Hernández Parrodi, Höllen, \& Pomberger, 2018a; Hernández Parrodi, Höllen, \& Pomberger, 2018b).

Fine fractions have been considered a potential substrate for intermediate or final cover layers for both operational landfills or closed and excavated landfills, which may represent a source of revenue (Hogland, 2010; Greedy, 2016). A previous study from the Austrian LAMIS project indicates that the fine fraction $<20 \mathrm{~mm}$ has a permeability of only $5.4510^{-8} \mathrm{~m} / \mathrm{s}$, if it has been compacted to a density of $1.26 \mathrm{~g} / \mathrm{cm}^{3}$ at an optimal water content of $23.2 \%$ and a temperature of $22^{\circ} \mathrm{C}$ (Liebetegger, 2015). Another option is use as soil substitute or construction aggregates (Spooren et al., 2013). For the latter application, the organic material should be removed from the fine fractions (Quaghebeur, et al., 2013), e.g. by physico-chemical treatment (Bhatnagar, et al., 2017). 
In the context of the NEW-MINE project a case study was conducted at Mont-Saint-Guibert (MSG) landfill in Belgium. Mechanical processing of the fine fractions 90 to 4.5 mm yielded median amounts of approx. $37.2 \mathrm{wt}$.\% inert, 9.0 wt.\% combustibles and 1.7 wt.\% total metals in dry state of the total amount of fine fractions $<90 \mathrm{~mm}$ (Hernández Parrodi et al., 2019c). In the latter case study, the extension of mechanical processing from a particle size of $10 \mathrm{~mm}$ to $4.5 \mathrm{~mm}$ increased the amount of recovered materials by around 10 wt.\% (Hernández Parrodi et al., 2019c), thus representing an additional amount of resource potential in comparison with previous studies in which particle sizes below $10 \mathrm{~mm}$ were not processed (Wanka, Münnich, \& Fricke, 2017). However, fine fractions $<4.5 \mathrm{~mm}$ which, due to their fine grain size are not suitable for separation either manually or using sensor-based technologies, remain highly challenging (Küppers, et al., 2019). Direct sorting technologies such as magnetic and eddy-current separation may be applied in the recovery of ferrous and non-ferrous metals, respectively, down to a particle size of 4.5 mm (Hernández Parrodi et al., 2019c; Lucas et al., 2019); however, these materials only account for a small amount of the total quantity of fine fractions, leaving behind a large share of fine fractions $<4.5 \mathrm{~mm}$ - composed mainly of weathered inorganic and decomposed organic matter (Hernández Parrodi, et al., 2019a).

In view of the characteristics of the fine fractions $<4.5$ $\mathrm{mm}$, being a mixture of organic compounds and mineral phases, utilisation as a soil substitute has been discussed (Hernández Parrodi, Höllen, \& Pomberger, 2018b; Hernández Parrodi et al., 2019c). Soils have been defined as the uppermost biologically active part of the Earth's crust, contributing to promoting soil functions (Scheffer \& Schachtschabel, 2018). Soil sealing leads to a loss of these functions, thus constituting a major environmental concern (Scalenghe \& Marsan, 2009). Additionally, approx. 25 million tons of excavated soils are landfilled in Austria every year (Federal Ministry for Sustainability and Tourism, 2017). Consequently, to maintain soil functions, soil substitute materials (Federal Ministry for Sustainability and Tourism, 2017) are produced for recultivation purposes. In Austria, legal requirements dictate the production of soil substitutes from waste, particularly to prevent recirculation of contaminants (Austrian Standards, 2013).

The fine fractions $<4.5 \mathrm{~mm}$ of landfill mining materials are rich in both organic and inorganic contaminants compared to the bulk of excavated materials (Burlakovs et al., 2016). Results of tests conducted on these fractions show how most of the potentially toxic elements studied (As, Ba, Cd, Co, Cr, Cu, Fe, Mg, Mn, Ni, Pb, Sb and $\mathrm{Zn}$ ) were bound to fractions of low extractability. This suggests that the fraction could be used as a low-risk cover material during environmental site remediation, landfill recultivation and land restoration, although further environmental analysis should first be performed due to the low mobility and leaching potential of toxic metals. In several countries total contents may also be used as limit values for the recycling of wastes inhibiting the utilization of wastes even at low leachability. A Swedish study reported how the total contents of zinc $(\mathrm{Zn})$, barium $(\mathrm{Ba})$ and chromium $(\mathrm{Cr})$ in fine fractions of landfilled material were above threshold values for contaminated soil (Jani et al., 2016). In this context, it should be considered that many metals may not only pose a threat to the environment, but also contribute to the resource potential of fine fractions (Burlakovs et al., 2018). An additional concern is associated with the presence of organic carbon, which may lead to the formation of methane (Mönkäre, Palmroth \& Rintala, 2016). Thus, utilization of the entire fine fractions $<4.5 \mathrm{~mm}$ for protection of natural resources might contradict the aim of waste management to protect human health and the environment by removing contaminants from a circular economy (Republic of Austria, 2002).

Consequently, to achieve all three aims of waste management, i.e. protection of human health, protection of the environment and protection of natural resources, separation of fine fractions $<4.5 \mathrm{~mm}$ into a contaminant-depleted fraction for recycling as soil substitute and a contaminant-enriched fraction for disposal at a sanitary landfill is mandatory.

Advanced separation technologies for grain size ranges below $4.5 \mathrm{~mm}$ are state-of-the-art in mineral processing, e.g. flotation (Peleka, Gallios, \& Matis, 2017), electrostatic separation (Kelly \& Spottiswood, 1989) or selective leaching of individual mineral phases (Lane et al., 2016), although detailed knowledge of the phase composition of the material is required. Due to the frequent lack of relevant information with regard to fine fractions from landfill mining, often also associated with significantly higher costs, this study tested a more simple approach, i.e. the screening and dry abrasion of surface defilements (i.e. impurities).

The first working hypothesis for this treatment was based on the knowledge that contaminants are enriched in the finest fraction, thus implying that even in the range $<4.5 \mathrm{~mm}$ separation between a clean coarser fraction and a contaminated finer fraction might be achieved.

The second working hypothesis referred to mobility of contaminants in the fine fraction: Although fine fractions of landfill mining materials are often described as soil-like material (Hernández Parrodi, Höllen, \& Pomberger, 2018b; Hernández Parrodi et al., 2019c) no studies have been conducted to date to assess their mineralogical composition. However, detailed knowledge is not only necessary for advanced separation technologies, but also to gain a deeper understanding of the leachability of heavy metals related to their mineral host phases (Vollprecht, et al., 2019). Existing studies on the mobility of contaminants from LFM fine fractions (Burlakovs, et al., 2016) follow the approach of sequential extraction, but do not explicitly address mineralogy of the fine fraction.

Consequently, our second hypothesis suggests that the mineralogy of (E)LFM fine fractions is related to leachability, as is the case for other materials such as slags (Neuhold, et al., 2019) and rocks (Vollprecht, et al., 2019).

To summarise, we present here the first study of fine fractions from landfill mining, including a comprehensive mineralogical analysis with particular emphasis on inorganic contaminants present and related leaching behaviour. 


\section{MATERIALS AND METHODS}

\subsection{Materials}

Fine fractions $<4.5 \mathrm{~mm}$ were obtained from mechanical processing of fine fractions $<90 \mathrm{~mm}$ from MSG landfill, Belgium, performed by Hernández Parrodi et al., 2019c (Figure 1). Fractions were produced after sieving composite samples of batches 1 and 2 of fine fractions $<90 \mathrm{~mm}$; first at $30 \mathrm{~mm}$, subsequently at $10 \mathrm{~mm}$ and finally at 4.5 $\mathrm{mm}$ at optimal water content (15 wt.\%) and in dry state. Additionally, particles ranging from 90 to $30 \mathrm{~mm}, 30$ to 10 $\mathrm{mm}$ and 10 to $4.5 \mathrm{~mm}$ were sieved once more at $4.5 \mathrm{~mm}$ after a series of mechanical processing steps (i.e. extraction of ferrous and non-ferrous metals, density separation and sensor-based sorting), with the purpose of removing released surface defilements. The subsequently produced fractions $<4.5 \mathrm{~mm}$ were combined with fine fractions $<4.5$ $\mathrm{mm}$ for further handling. Total amount of fine fractions $<4.5 \mathrm{~mm}$ corresponded to $42.9 \mathrm{wt}$.\% and $42.7 \mathrm{wt}$.\% of fine fractions $<90 \mathrm{~mm}$ at optimal water content and in dry state, respectively (Hernández Parrodi et al., 2019c). In turn, the fine fractions $<90 \mathrm{~mm}$ accounted for approx. $77 \mathrm{wt}$.\% of the total amount of processed material in raw state from the MSG landfill (Hernández Parrodi et al., 2019a). Additional details on the fine fractions $<90 \mathrm{~mm}$ and mechanical processing, as well as further information about the sampling method and preparation of composite samples, are reported in Hernández Parrodi et al., 2019a and Hernández Parrodi et al., 2019c.

A total of six composite laboratory samples $(n=6)$, containing both batch 1 and batch 2, were obtained from composite samples of the fine fractions $<4.5 \mathrm{~mm}$ at optimal water content $(n=3)$ and in dry $(n=3)$ state, and the physico-chemical properties determined. In line with the properties detected and the findings of the study on particle size distribution and water content in the fine fractions $<90 \mathrm{~mm}$ performed by Hernández Parrodi et al., 2019c, additional mechanical processing of the fine fractions $<4.5 \mathrm{~mm}$ was designed. The study of particle size distribution and water content revealed that in order to achieve adequate particle size classification of the fine fractions below $3 \mathrm{~mm}$, further reduction of the water content is needed, particularly below $0.6 \mathrm{~mm}$. Therefore, only composite samples of batches 1 and 2 of the fine fractions $<4.5 \mathrm{~mm}$ in dry state were used for further mechanical processing. This suggests that the composite samples at optimal water content state would need to be dried and processed in the mechanical processing. It is important to note that the state referred to as "the dry state" does not correspond to a strictly dry state, but rather to an average water content of $1.5 \mathrm{wt} . \%$ due to absorption/adsorption of ambient moisture by the material throughout the whole mechanical processing.

Additionally, six soil samples were taken from the landfill and the surrounding area for comparison of determined heavy metal concentrations with geological background concentrations.

\subsection{Mechanical Processing}

The fine fractions $<4.5 \mathrm{~mm}$ were subjected to dry-mechanical processing consisting of particle size classification steps (i.e. sieving), followed by a surface cleaning process, driven by superficial erosion (surface attrition), and a second particle size classification step for elimination of loosened surface defilements and detritus. Figure 2 displays a graphic representation of the dry-mechanical processing applied.

A total of eight composite samples $(n=8)$ of the fine fractions $<4.5 \mathrm{~mm}$ of batch $1(n=4)$ and batch $2(n=4)$ in dry state were sieved further into four particle size ranges (i.e. 4.5 to $1.6 \mathrm{~mm}, 1.6$ to $0.5 \mathrm{~mm}, 0.5$ to $0.18 \mathrm{~mm}$ and $<0.18 \mathrm{~mm}$ ). The samples subsequently underwent chemical analysis to identify the particle size range(s) featuring

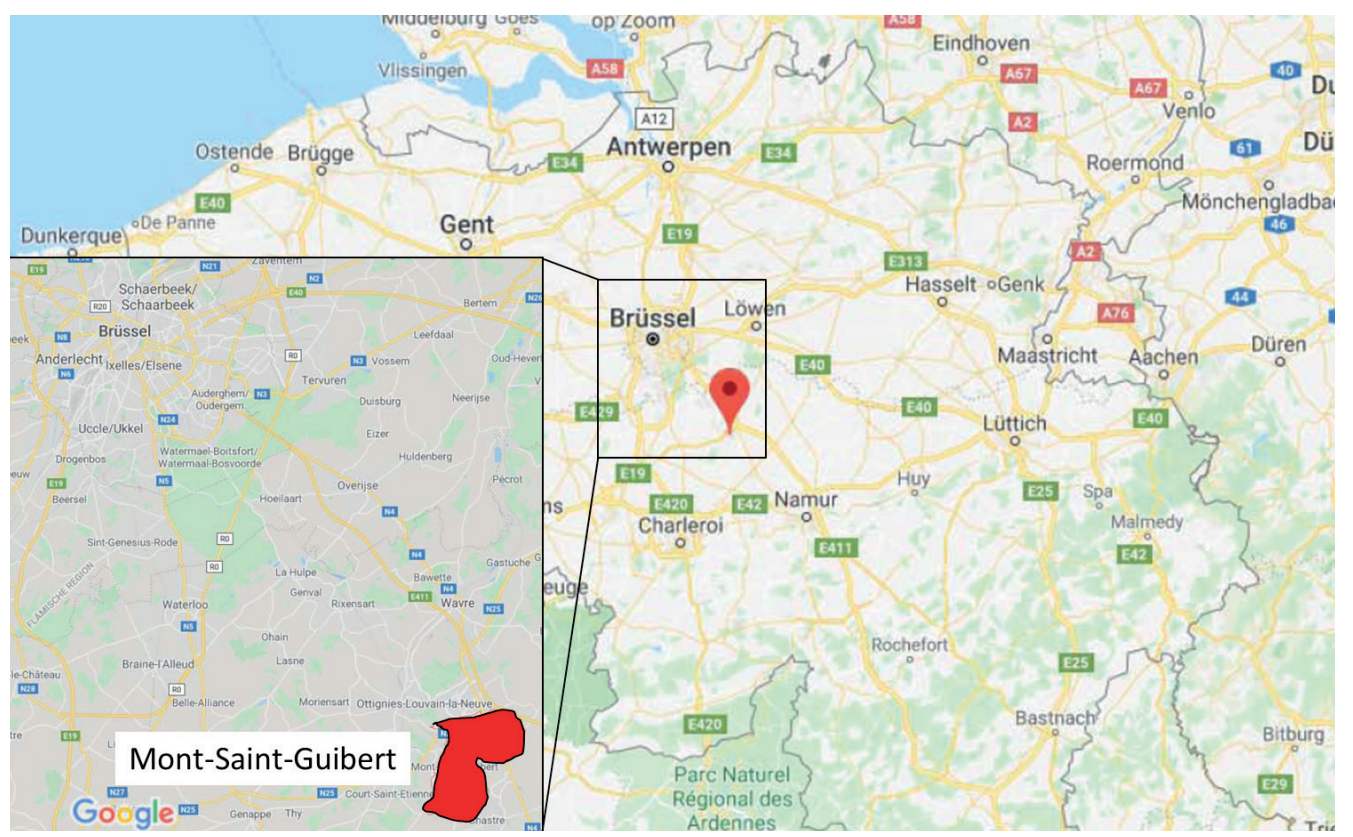

FIGURE 1: Location of the Mont-Saint-Guibert landfill. 


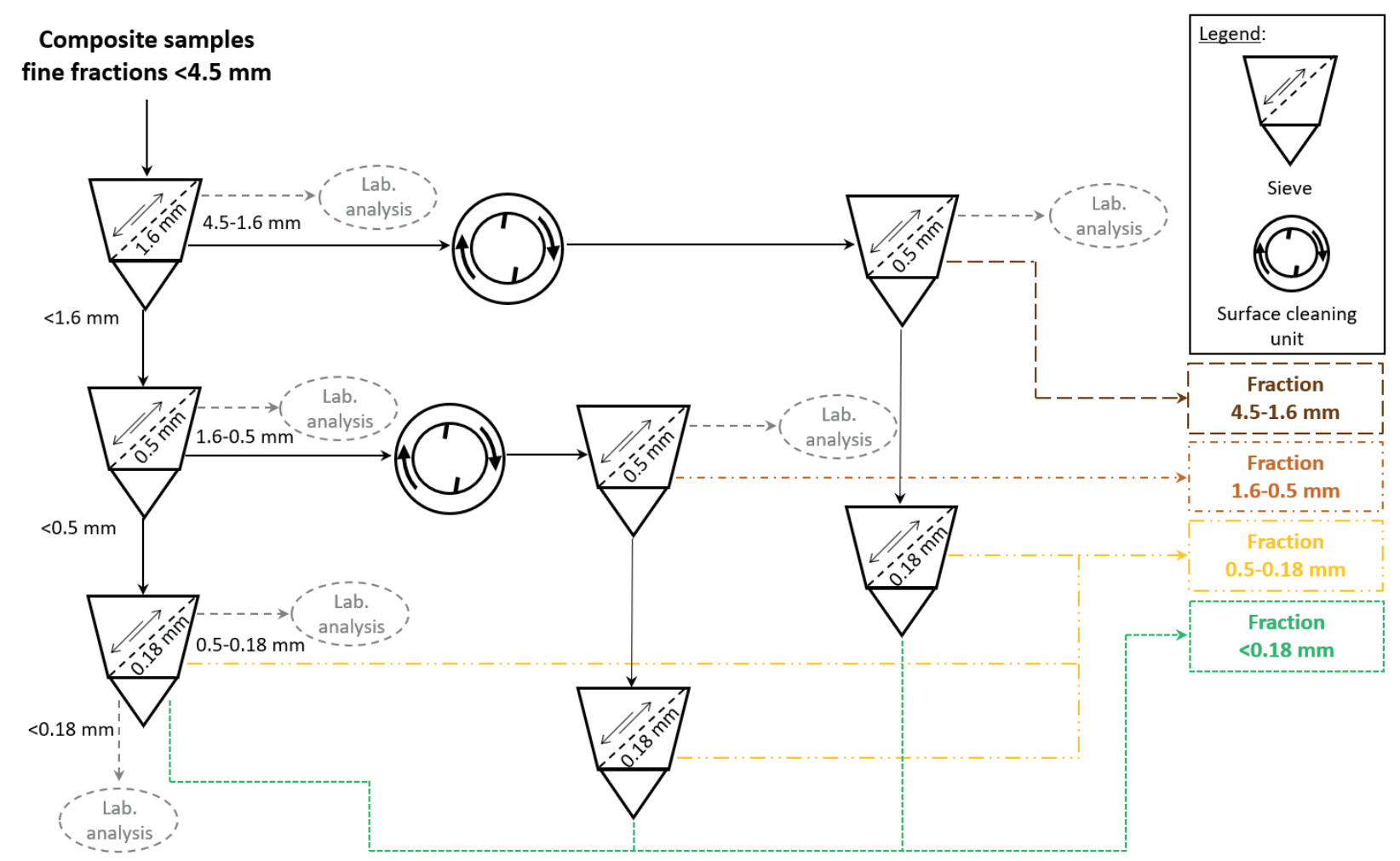

FIGURE 2: Scheme of dry-mechanical processing of the fine fractions $<4.5 \mathrm{~mm}$.

the highest concentrations of pollutants and to determine whether the quality of fine fractions $<4.5 \mathrm{~mm}$ could be improved through further mechanical processing. For this purpose, composite samples were further sieved in a vibratory sieve tower (Retsch AS 200) with woven wire test sieves and squared openings of $1.6 \mathrm{~mm}, 0.5 \mathrm{~mm}$ and 0.18 $\mathrm{mm}$ at an amplitude of $100 \%$. Due to the amount of material, prior to sieving, each composite sample was divided into two or three subsamples. Each subsample was sieved for 1 minute to simulate an industrial sieving process, and the amounts of all particle size ranges determined using a precision scale (Sartorius ENTRIS6202-1S; resolution of $0.01 \mathrm{~g})$. After sieving, three composite samples $(\mathrm{n}=3)$ were used to determine the physico-chemical properties of each of the four particle size ranges produced. In turn, four composite samples $(n=4)$, including both batch 1 and batch 2 , for each of the particle size ranges 4.5 to $1.6 \mathrm{~mm}$ and 1.6 to $0.5 \mathrm{~mm}(\mathrm{n}=8)$ were further mechanically processed by surface cleaning. For this purpose, the particle size ranges 4.5 to $1.6 \mathrm{~mm}$ and 1.6 to $0.5 \mathrm{~mm}$ underwent further processing in a surface cleaning unit, which consisted of an automatic concrete mixer (Atika BM $125 \mathrm{~S}$ ) rotated at a speed of $30 \mathrm{rpm}$ with an inclination of $45^{\circ}$ for 10 minutes for each composite sample (Figure 3 ). The objective of the surface cleaning process was to decrease the concentration of pollutants in the coarser particle size ranges (i.e. 4.5 to $1.6 \mathrm{~mm}$ and 1.6 to $0.5 \mathrm{~mm}$ ), since it was assumed that the majority of pollutants would be present in the finer particle size ranges ( 0.5 to $0.18 \mathrm{~mm}$ and $<0.18 \mathrm{~mm}$ ), which would attach to the surface of the coarser particle size ranges as surface defilements.
One composite sample from each set of four was stored for future use in additional laboratory analyses or alternative processing steps. As shown in Figure 2, a dry surface cleaning process was followed by 1 -minute sieving at 0.5 $\mathrm{mm}$ and $0.18 \mathrm{~mm}$ using the previously described vibrating sieve. Finally, the obtained composite samples were used to determine the physico-chemical properties of fractions subjected to the surface cleaning process, with the aim of analysing and evaluating effectiveness and performance.

\subsection{Chemical Analyses}

Three of the composite samples $<4.5 \mathrm{~mm}$ were analysed for chemical composition (20 oxides) by means of X-ray fluorescence (XRF) spectrometry using fusion tablets according to DIN EN ISO 12667 at CRB GmbH, Hardegsen, Germany. Loss of ignition (LOI) was determined according to DIN EN ISO 26845 at $1025^{\circ} \mathrm{C}$. The mean value of the three analyses was used for further considerations.

Three composite samples of each of the fractions 4.5 to $1.6 \mathrm{~mm}, 1.6$ to $0.5 \mathrm{~mm}, 0.5$ to $0.18 \mathrm{~mm}$ and $<0.18 \mathrm{~mm}$ $(n=12)$ were chemically analysed at the laboratory of the Chair of Waste Processing Technology and Waste Management (AVAW) of the Montanuniversität Leoben. Additionally, the chemical composition of three composite samples of each of the fractions 4.5 to $1.6 \mathrm{~mm}$ and 1.6 to $0.5 \mathrm{~mm}$ $(n=6)$ was determined subsequent to dry surface cleaning to compare the concentrations of different pollutants prior to and following dry surface cleaning.

Chemical analyses were generally conducted according to ÖNORM S 2122 ("Soils from Wastes"), which was also taken as a basis for reference values of different parame- 


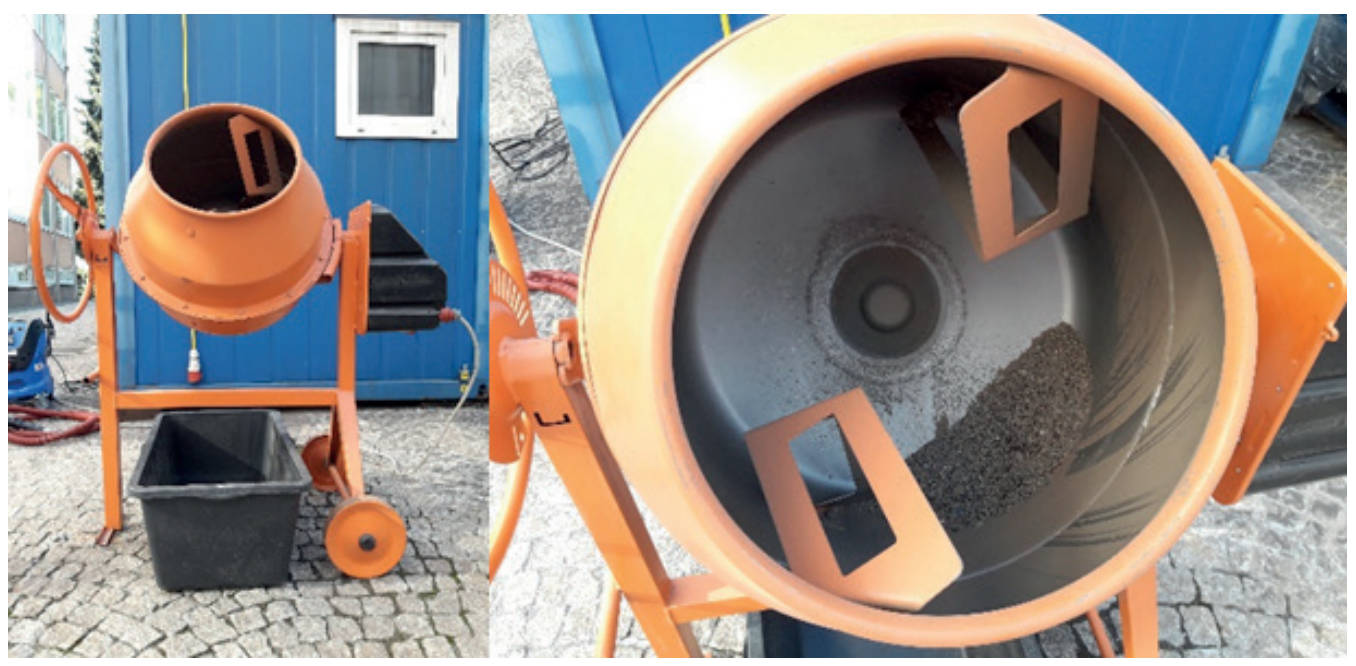

FIGURE 3: Scheme of dry-mechanical processing of the fine fractions $<4.5 \mathrm{~mm}$.

ters to be complied with. Additionally, as no limit values for pseudo-total contents (aqua regia digestion) are provided in ÖNORM S2122, limit values for pseudo-total contents of contaminants for excavated soil landfills (Federal Ministry for Agriculture, Forestry, Environment and Water Management, 2008) and recycling of excavated soil (Federal Ministry for Sustainability and Tourism, 2017) were used for comparison. Samples were analysed for total carbon (TC), total organic carbon (TOC, both according to EN 13137), nitrogen $(\mathrm{N})$, adsorbable organic halogens (AOX, according to DIN 38414-18), polycyclic aromatic hydrocarbons (PAHs, according to ÖNORM L 1200), polychlorinated biphenyls (PCBs, according to DIN 38414-20), the cohesion number (KH value, according to ÖNORM S2122-2) and the hydrocarbon index (according to ÖNORM EN 14039). TOC/N ratio was calculated according to ÖNORM S 21222. Furthermore, physical properties, including dry and wet density (ÖNORM S 2122-1) and water content (according to ÖNORM L 1062), were determined.

For the determination of pseudo-total metal content, samples were digested in aqua regia according to ÖNORM EN 13657. Metals were determined in the digested sample by means of inductively coupled plasma mass spectrometry (ICP-MS) according to ÖNORM EN ISO 17294-2.

Water-soluble constituents were determined according to ÖNORM L 1092 and ÖNORM S 2122-1. As the production of a saturated water extract was not possible, the following procedure was applied: $100 \mathrm{~g}$ air-dried sample was suspended in $500 \mathrm{~g}$ pure water and shaken for $2 \mathrm{~h}$ in an overhead shaker. Solids were separated from the solution by a centrifuge ( $15 \mathrm{~min}$ at 5,500 rotations per $\mathrm{min}$ ) and subsequent filtration $(0.45 \mu \mathrm{m})$. The resulting leachates were analysed for $\mathrm{pH}$ (according to ISO 10523), electric conductivity (according to DIN EN 27888), permanganate index ( $C_{\text {ox }}$, according to ÖNORM EN ISO 8467), dissolved organic carbon (DOC, according to ÖNORM EN 1484), anions (i.e. fluoride, chloride, nitrate, sulphate and phosphate, according to DIN EN ISO 10304-1), ammonium (according to DIN 38406-5) and other cations (according to ÖNORM EN ISO 17294-2). Three composite samples $(n=3)$ were analysed for each parameter and the arithmetic mean, together with the standard error (confidence interval of $95 \%$ ), were calculated based on the results of laboratory analysis.

Finally, the six soil samples obtained from the landfill and surrounding areas were analysed for $\mathrm{Ba}, \mathrm{Ge}, \mathrm{Cd}, \mathrm{Cr}$, $\mathrm{Co}, \mathrm{Cu}, \mathrm{Ge}, \mathrm{As}, \mathrm{Hf}, \mathrm{Sc}, \mathrm{Li}, \mathrm{Au}, \mathrm{Ag}$ by means of inductively coupled plasma optical emission spectrometry (ICP-OES) at the Chair of Process Metallurgy and Metal Recycling at RWTH Aachen University. Furthermore, S and C were determined in the same laboratory by combustion and subsequent determination of oxides in the off-gas.

\subsection{Mineralogical Analyses}

Modal mineral composition of the fractions $<0.18 \mathrm{~mm}$ and 0.18 to $1.5 \mathrm{~mm}$ from batch 1 and batch 2 was investigated by means of X-ray powder diffraction (XRD) analysis. Two powdered samples $(n=2)$ of each particle size range and batch were analysed using a PANalytical X'Pert Pro diffraction instrument (CoKa radiation $(\lambda=1.79 \AA)$ ), $40 \mathrm{~mA}$, $45 \mathrm{kV}$ ) and PANalytical HighScore Plus software package at the Institute of Applied Geosciences, Graz University of Technology. Diffractograms were automatically quantified using Rietveld refinement. Resulting net lower limits of detection were in the order of 2 - $5 \mathrm{wt}$.\%, indicating the potential presence of minerals at lower concentrations, although not detectable by XRD.

The distribution of $\mathrm{C}, \mathrm{S}, \mathrm{Pb}, \mathrm{Si}, \mathrm{Cu}, \mathrm{Al}, \mathrm{O}, \mathrm{K}, \mathrm{Ca}, \mathrm{P}, \mathrm{Zn}, \mathrm{Na}$, $\mathrm{Mg}, \mathrm{Ba}$ and $\mathrm{Fe}$ was determined for the same samples by electron probe microanalyses (EPMA) using the JEOL JXA 8200 instrument installed at the Chair of Resource Mineralogy, Montanuniversität Leoben. Polished sections were carbon coated (EMITECH K950X) to minimize charging under the electron beam. Element maps of mineral phases were conducted using wavelength-dispersive spectrometers (WDX). Heavy-metal containing phases were qualitatively analysed for chemical composition using energy dispersive spectrometers (EDX). The instrument was operated in high vacuum ( $\left.<1.6510^{-5} \mathrm{mbar}\right)$, with $15 \mathrm{kV}$ acceleration voltage, $10 \mathrm{nA}$ beam current (on Faraday cup), and with beam diameter set to spot size $(» 1 \mu \mathrm{m})$. 


\section{RESULTS AND DISCUSSION}

\subsection{Mechanical Processing}

As described in Section 2 all composite samples of the fine fractions $<4.5 \mathrm{~mm}$ in the dry state were initially sieved at $1.6 \mathrm{~mm}, 0.5 \mathrm{~mm}$ and $0.18 \mathrm{~mm}$. Half of the resulting composite samples of particle size ranges 4.5 to $1.6 \mathrm{~mm}, 1.6$ to $0.5 \mathrm{~mm}, 0.5$ to $0.18 \mathrm{~mm}$ and $<0.18 \mathrm{~mm}$ were used to determine the physico-chemical properties of fractions prior to the surface cleaning process. This process was undertaken to assess whether enrichment of any of the studied parameters, such as heavy metals, PAHs and PCBs, among others, occurred in the presence of any specific particle size distribution and, thus determine whether the same parameters could be concentrated in a certain particle size range by means of particle size classification. Additionally, the physico-chemical characteristics of each particle size range were used as a reference to evaluate the effects of the surface cleaning process. Figure 4 displays the general mass balance of the mechanical processing approach studied in this investigation. Figures for the general mass balance were calculated using the arithmetic mean of the four composite samples $(n=4)$ processed in the tested mechanical processing, based on the average amount of fine fractions $<4.5 \mathrm{~mm}$ (42.9 wt.\%) versus the total quantity of fine fractions $<90 \mathrm{~mm}$ processed in dry state in our previous study (Hernández Parrodi et al., 2019c).

The general mass balance in Figure 4 revealed amounts corresponding to approx. 13.9 wt.\%, 10.8 wt.\%, 12.7 wt.\% and $5.6 \mathrm{wt}$ \% for the particle size ranges 4.5 to $1.6 \mathrm{~mm}, 1.6$ to $0.5 \mathrm{~mm}, 0.5$ to $0.18 \mathrm{~mm}$ and $<0.18 \mathrm{~mm}$, respectively. This highlighted a tendency of the amount of material to decrease in line with reduction in particle size, with the exception of particle size range $0.5 \mathrm{~mm}$ to $0.18 \mathrm{~mm}$, featuring a higher amount than the particle size range $1.6 \mathrm{~mm}$ to 0.5 $\mathrm{mm}$. Images of the obtained fractions are shown in Figure 5.

Directly after the initial sieving steps at $1.6 \mathrm{~mm}, 0.5 \mathrm{~mm}$ and $0.18 \mathrm{~mm}$, composite samples of particle size ranges $4.5 \mathrm{~mm}$ to $1.6 \mathrm{~mm}$ and $1.6 \mathrm{~mm}$ to $0.5 \mathrm{~mm}$ were processed in the surface cleaning unit and subsequently sieved at 0.5 $\mathrm{mm}$ and $0.18 \mathrm{~mm}$. An average material loss of approx. 1.2 wt.\% due to surface cleaning and subsequent sieving was estimated, whereas an amount of about $3.4 \mathrm{wt} . \%$ of liberated surface defilements and detritus after the surface cleaning process was calculated, compared to the total amount of fine fractions $<90 \mathrm{~mm}$ processed in the dry state. As only a modest average water content of $1.5 \mathrm{wt} . \%$ (Table 4) was determined in the processed composite samples, further influence of ambient moisture was deemed negligible in regards to general mass balance. Respective amounts of 0.9 wt. \% and $0.7 \mathrm{wt} . \%$ of the fraction $0.5 \mathrm{~mm}$ to $0.18 \mathrm{~mm}$ were obtained in particle size ranges $4.5 \mathrm{~mm}$ to $1.6 \mathrm{~mm}$ and 1.6 $\mathrm{mm}$ to $0.5 \mathrm{~mm}$ after sieving at $0.18 \mathrm{~mm}$, while quantities of $1.3 \mathrm{wt} . \%$ and $0.6 \mathrm{wt} . \%$ of the fraction $<0.18 \mathrm{~mm}$ were yielded, respectively. Therefore, the dry-mechanical processing used in this study produced total amounts of approx. 11.7 wt.\% fine fractions $4.5 \mathrm{~mm}$ to $1.6 \mathrm{~mm}$ (clean), $9.5 \mathrm{wt}$ \% fine

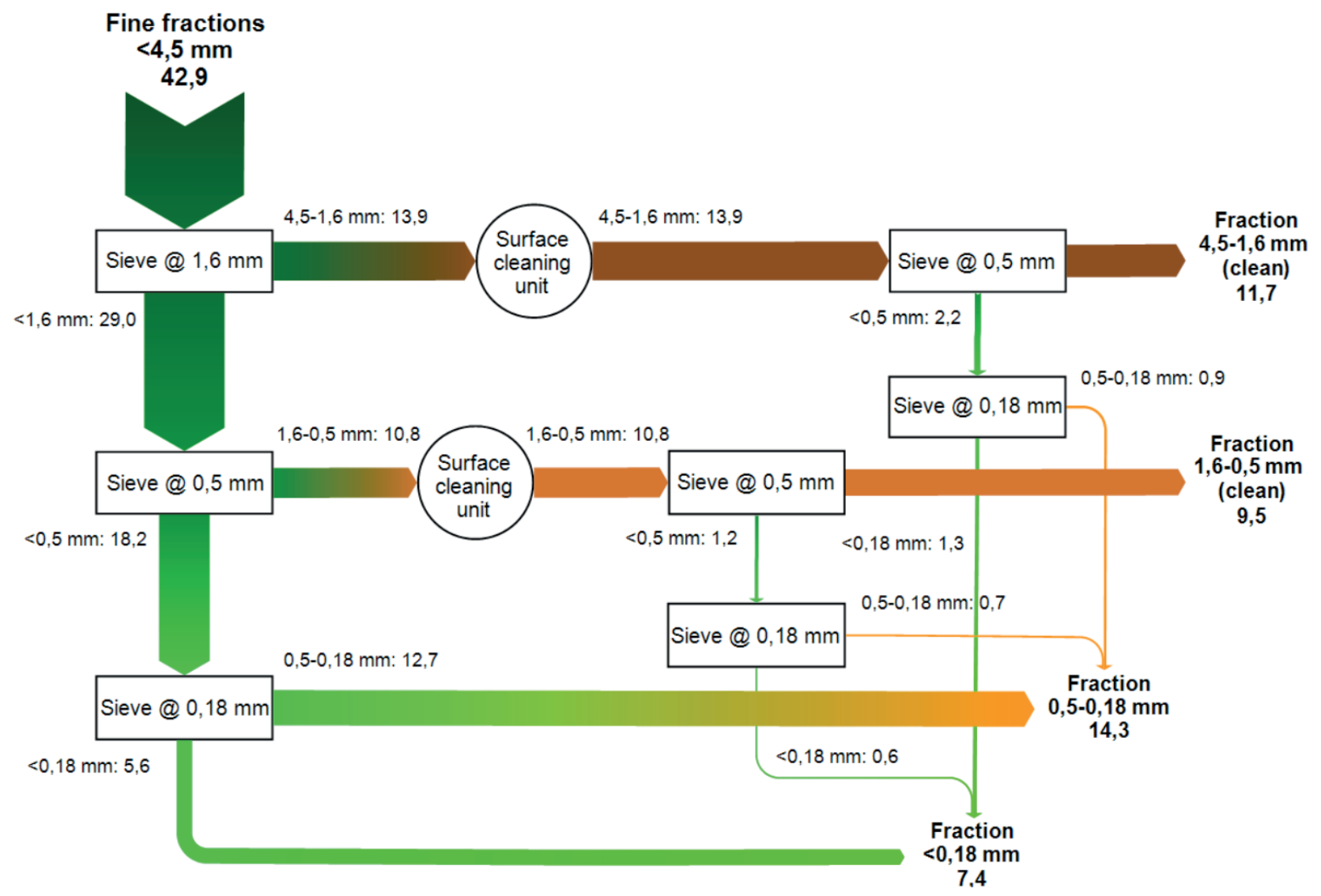

FIGURE 4: General mass balance of the mechanical processing of the fine fractions $<4.5 \mathrm{~mm}$, figures in wt.\%. 
fractions $1.6 \mathrm{~mm}$ to $0.5 \mathrm{~mm}$ (clean), $14.3 \mathrm{wt} . \%$ fine fractions $0.5 \mathrm{~mm}$ to $0.18 \mathrm{~mm}$ and $7.4 \mathrm{wt} . \%$ fine fractions $<0.18$ $\mathrm{mm}$. Images of the coarser particle size ranges $4.5-1.6 \mathrm{~mm}$ and $1.6-0.5 \mathrm{~mm}$ after the dry surface cleaning process and subsequent sieving at $0.5 \mathrm{~mm}$ and $0.18 \mathrm{~mm}$ are shown in Figure 6.

\subsection{Chemical Analyses}

The chemical composition of the entire fine fraction $<4.5 \mathrm{~mm}$ is displayed in Table $1 . \mathrm{SiO}_{2}$ represented the main chemical component at approx. 70 wt.\%, followed by LOI (14 wt.\%), $\mathrm{CaO}$ (5 wt.\%), $\mathrm{Fe}_{2} \mathrm{O}_{3}$ and $\mathrm{Al}_{2} \mathrm{O}_{3}$ (each 4 wt.\%). All other analysed chemical components were below $1 \mathrm{wt} . \%$.
Compared to the average composition of the Earth's Crust (Taylor, 1964), samples were rich in $\mathrm{SiO}_{2}$, but depleted in $\mathrm{Al}_{2} \mathrm{O}_{3}$. This suggests that either $\mathrm{SiO}_{2}$-enriched materials, e.g. building sand, had been landfilled, or that $\mathrm{SiO}_{2}$ had become enriched following deposition in the landfill. However, usually due to weathering, not only $\mathrm{SiO}_{2}$, but also $\mathrm{Al}_{2} \mathrm{O}_{3}$ are found to be enriched, thus supporting the first hypothesis, i.e. landfilling of $\mathrm{SiO}_{2}$-enriched materials.

Pseudo-total contents of chemical elements in the investigated samples are summarized in Table 2. The pseudo-total contents of almost all elements in the fraction 0.5 to $0.18 \mathrm{~mm}$ corresponded to approximately half the values obtained from the coarser ( 1.6 to $0.5 \mathrm{~mm}$ and 4.5 to 1.6
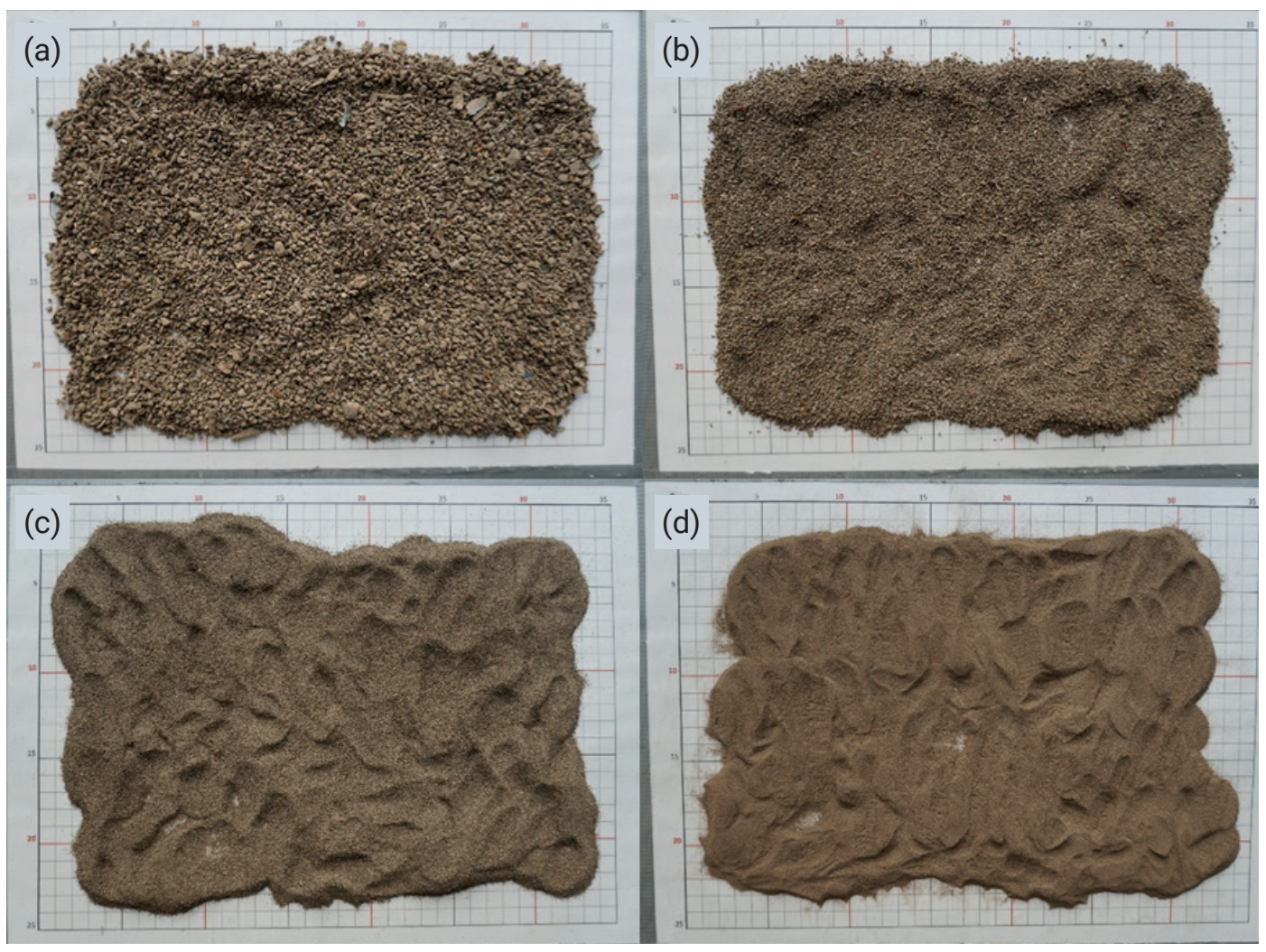

FIGURE 5: Particle size ranges (a) 4.5 to $1.6 \mathrm{~mm}$, (b) 1.6 to $0.5 \mathrm{~mm}$, (c) 0.5 to $0.18 \mathrm{~mm}$ and (d) $<0.18 \mathrm{~mm}$ of the fine fractions $<4.5 \mathrm{~mm}$ after first sieving steps.

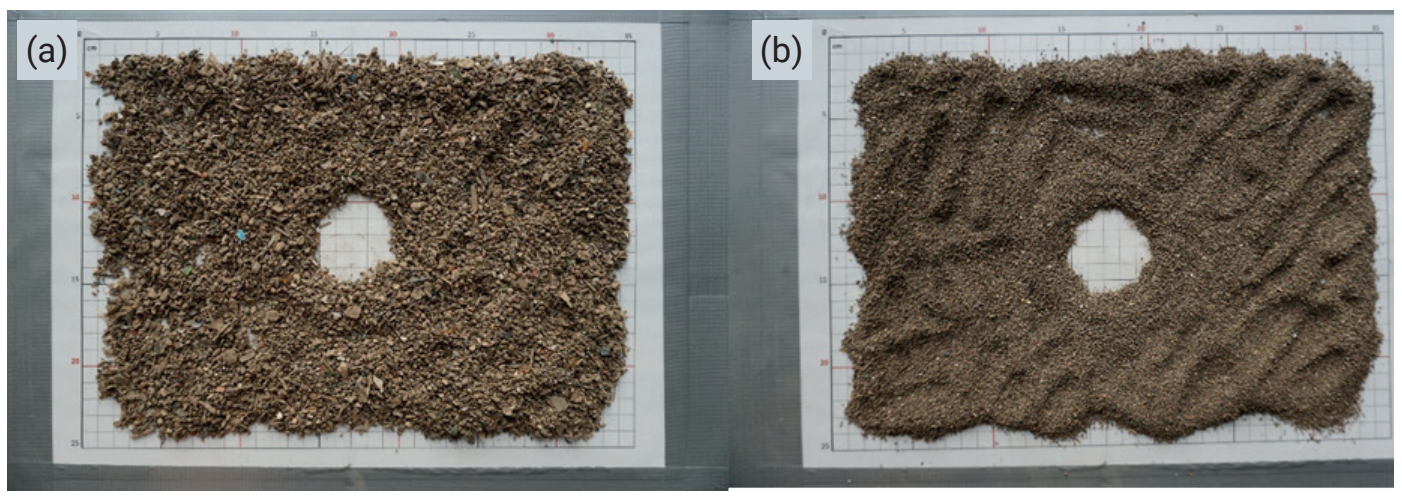

FIGURE 6: Particle size ranges (a) 4.5 to $1.6 \mathrm{~mm}$ and (b) 1.6 to $0.5 \mathrm{~mm}$ of the fine fractions $<4.5 \mathrm{~mm}$ after the dry surface cleaning process and second sieving step. 
TABLE 1: Chemical composition (fusion tablet, data refer to dry matter (DM)) of the fine fractions $<4.5 \mathrm{~mm}$.

\begin{tabular}{|c|c|c|c|c|c|}
\hline Parameter & Unit & $\begin{array}{c}<4.5 \\
\text { mm_1 }\end{array}$ & $\begin{array}{c}<4.5 \\
\mathrm{~mm} \_2\end{array}$ & $\begin{array}{c}<4.5 \\
\text { mm_3 }\end{array}$ & Mean \\
\hline $\mathrm{SiO}_{2}$ & wt.\% & 69.37 & 70.01 & 69.80 & 69.73 \\
\hline $\mathrm{Al}_{2} \mathrm{O}_{3}$ & wt.\% & 4.00 & 3.98 & 4.00 & 3.99 \\
\hline $\mathrm{Fe}_{2} \mathrm{O}_{3}$ & wt. \% & 4.52 & 4.41 & 4.48 & 4.47 \\
\hline $\mathrm{Cr}_{2} \mathrm{O}_{3}$ & wt.\% & 0.01 & 0.01 & 0.01 & 0.01 \\
\hline $\mathrm{MnO}$ & wt.\% & 0.04 & 0.04 & 0.04 & 0.04 \\
\hline $\mathrm{TiO}_{2}$ & wt.\% & 0.28 & 0.28 & 0.29 & 0.28 \\
\hline $\mathrm{V}_{2} \mathrm{O}_{5}$ & wt.\% & 0.01 & 0.01 & 0.01 & 0.01 \\
\hline $\mathrm{P}_{2} \mathrm{O}_{5}$ & wt.\% & 0.24 & 0.24 & 0.23 & 0.23 \\
\hline $\mathrm{CaO}$ & wt.\% & 4.90 & 4.76 & 4.85 & 4.84 \\
\hline $\mathrm{MgO}$ & wt.\% & 0.62 & 0.61 & 0.63 & 0.62 \\
\hline $\mathrm{K}_{2} \mathrm{O}$ & wt.\% & 0.79 & 0.79 & 0.83 & 0.80 \\
\hline $\mathrm{Na}_{2} \mathrm{O}$ & wt.\% & 0.37 & 0.38 & 0.38 & 0.38 \\
\hline $\mathrm{SO}_{3}$ & wt.\% & 0.82 & 0.71 & 0.83 & 0.79 \\
\hline $\mathrm{ZrO}_{2}$ & wt.\% & 0.02 & 0.02 & 0.02 & 0.02 \\
\hline $\mathrm{NiO}$ & wt.\% & 0.01 & 0.01 & 0.01 & 0.01 \\
\hline $\mathrm{CuO}$ & wt.\% & 0.02 & 0.03 & 0.02 & 0.02 \\
\hline $\mathrm{ZnO}$ & wt.\% & 0.11 & 0.11 & 0.11 & 0.11 \\
\hline $\mathrm{Rb}_{2} \mathrm{O}$ & wt.\% & 0.01 & 0.01 & 0.01 & 0.01 \\
\hline $\mathrm{SrO}$ & wt.\% & 0.02 & 0.02 & 0.02 & 0.02 \\
\hline $\mathrm{BaO}$ & wt.\% & 0.06 & 0.06 & 0.07 & 0.06 \\
\hline LOI & wt.\% & 13.72 & 13.47 & 13.32 & 13.50 \\
\hline Sum & wt.\% & 99.92 & 99.92 & 99.91 & 99.92 \\
\hline
\end{tabular}

$\mathrm{mm})$ and finer $(<0.18 \mathrm{~mm})$ fractions. The sum of all analytes accounts for $5.8 \mathrm{wt}$.\% of the fraction 0.5 to $0.18 \mathrm{~mm}$ and 9.9 to $12.6 \mathrm{wt} . \%$ for the three other fractions. This can be explained by different dissolution behaviour of this fraction during aqua regia digestion. Silicon concentrations were below $0.1 \mathrm{wt} . \%$ for all fractions, although $\mathrm{SiO}_{2}$ concentrations were about $70 \mathrm{wt}$.\% according to XRF, in agreement with the fact that aqua regia does not dissolve silicate minerals. Consequently, it is suggested that the fraction 0.5 to $0.18 \mathrm{~mm}$ may be richer in silicate minerals. Considering the lack of oxygen analyses, it can be estimated that approx. $85 \mathrm{wt} . \%$ of the samples (exceeding $90 \%$ wt for the fraction 0.5 to $0.18 \mathrm{~mm}$ ) are made up of silicates.

The main constituents were found to be Ca (2.4 wt.\% in the fraction 0.5 to $0.18 \mathrm{~mm}, 4.4-4.8 \mathrm{wt} . \%$ in the other fractions), Fe (1.9 wt.\% in the fraction 0.5 to $0.18 \mathrm{~mm}, 3.2 \mathrm{wt} . \%$ in the fraction $<0.18 \mathrm{~mm}$ and $4.8-5.0 \mathrm{wt}$ \% in the coarser fractions) and $\mathrm{Al}(0.7 \mathrm{wt} . \%$ in the fraction 0.5 to $0.18 \mathrm{~mm}, 1.1-1.3$ wt.\% in the other fractions). All other elements were below 1 wt.\%. Ca and Fe concentrations substantially matched the results obtained by XRF, whereas Al concentrations were significantly lower in digested samples compared to XRF measurements. This suggests that $\mathrm{Al}$ is bound to silicate minerals, whereas $\mathrm{Ca}$ and $\mathrm{Fe}$ are bound to more soluble phases such as carbonates and hydroxides, respectively.

The recycling of fine fractions from ELFM as soil substitute is not directly regulated in Austria. Soil substitutes may only be produced from a restricted list of wastes including excavated soil, but not specifically including (E)LFM materials. However, due to the soil-like character of the material, limit values for the recycling of excavated soil (Federal Ministry for Sustainability and Tourism, 2017) as soil substitute might be used as an approximation. Furthermore, limit values for excavated soil landfills (Federal Ministry for Agriculture, Forestry, Environment and Water Management, 2008), which are almost identical to limit values established for recycling, thus further supporting the need to assess environmental impact of the investigated material. Both these limit values and also concentrations detected refer to pseudo-total content obtained by aqua regia digestion.

In general, the pseudo-total contents of contaminants were in the same range as those observed for the Kudjape landfill, Latvia (Burlakovs et al., 2016). A comparison between determined values and limit values shows that pseudo-total contents of $\mathrm{Cr}, \mathrm{Co}$, As and $\mathrm{Ni}$ were below the limit values for all fractions, whereas determined values for $\mathrm{Cu}$, $\mathrm{Zn}, \mathrm{Cd}, \mathrm{Hg}$ and $\mathrm{Pb}$ were above the limit values for all fractions (except $\mathrm{Hg}$ for the fraction 0.5 to $0.18 \mathrm{~mm}$ ). This may imply either that $\mathrm{Cr}$, As, $\mathrm{Co}$ and $\mathrm{Ni}$ are only present in very low concentrations or that they are bound to the silicates or other low-soluble phases such as oxides. In the case of As, present as oxyanion, also strong sorption in the acidic $\mathrm{pH}$ might play a role, as the mineral surfaces are charged positively in this $\mathrm{pH}$ range. Conversely, $\mathrm{Cu}, \mathrm{Zn}, \mathrm{Cd}, \mathrm{Hg}$ and $\mathrm{Pb}$ represent chalcophilic elements, which are instead bound to sulphide minerals. Under oxidizing conditions, such as in aqua regia, these are easily dissolved. This suggests that this group of elements may be increasingly bound to sulphides or similar mineral phases, or adsorbed on surfaces of mineral or organic matter.

No trend was observed with regard to the enrichment or depletion of heavy metals in the different particle size ranges. This indicates the unsuitability of particle size classification in the range $<4.5 \mathrm{~mm}$ as a means of achieving limit values for pseudo-total content of heavy metals in the investigated ELFM fine fractions. As certain heavy metals (e.g. $\mathrm{Cd}$ and $\mathrm{Pb}$ ) are frequently present in glass products (especially in the past), and glass was not sorted out of these fractions, these elements might be bound to glass. Glass separation, e.g. by density separation, might represent a means of decreasing the content of these elements.

Furthermore, background concentrations of heavy metals in soil at the landfill site and surrounding areas should also be taken into account (Table 3), specifically to determine the extent to which the heavy metal concentrations should be attributed exclusively to waste disposed of at the landfill, and thus enable a conclusive assessment of heavy metal concentrations. Both investigated heavy metals and carbon content were below the limit value for excavated soil landfills in Austria (Federal Ministry for Agriculture, Forestry, Environment and Water Management, 2008). Consequently, the geogenic background concentration may be considered negligible.

In addition to heavy metals, organic contaminants were also found to partly exceed limit values for excavated soil landfills and recycling (Table 4). This was indeed the 
TABLE 2: Pseudo-total contents of the investigated fine fractions ( $n=3, s=1 \sigma)$, bold parameters are above threshold values, comparable data from Burlakovs et al (2016), limit values for excavated soil landfills according to (Federal Ministry for Agriculture, Forestry, Environment and Water Management, 2008), for recycling quality class BA according to (Federal Ministry for Sustainability and Tourism, 2017).

\begin{tabular}{|c|c|c|c|c|c|c|c|c|}
\hline Parameter & Unit & $4.5-1.6 \mathrm{~mm}$ & $1.6-0.5 \mathrm{~mm}$ & $0.5-0.18 \mathrm{~mm}$ & $<0.18 \mathrm{~mm}$ & $\begin{array}{l}\text { Burlakovs et al } \\
(2016)\end{array}$ & $\begin{array}{l}\text { Limit value for } \\
\text { excavated soil } \\
\text { landfills }\end{array}$ & $\begin{array}{l}\text { Limit value } \\
\text { for recycling } \\
\text { (class BA) }\end{array}$ \\
\hline $\mathrm{Li}$ & $\mathrm{mg} / \mathrm{kg} \mathrm{DM}$ & $11 \pm 0$ & $11 \pm 0$ & $5 \pm 0$ & $9 \pm 1$ & & - & \\
\hline $\mathrm{Be}$ & $\mathrm{mg} / \mathrm{kg} \mathrm{DM}$ & $<10$ & $<10$ & $<10$ & $<10$ & & - & \\
\hline B & $\mathrm{mg} / \mathrm{kg} \mathrm{DM}$ & $32 \pm 2$ & $36 \pm 2$ & $17 \pm 2$ & $26 \pm 2$ & & - & \\
\hline $\mathrm{Na}$ & $\mathrm{mg} / \mathrm{kg} \mathrm{DM}$ & $747 \pm 75$ & $827 \pm 69$ & $347 \pm 17$ & $587 \pm 57$ & & - & \\
\hline $\mathrm{Mg}$ & $\mathrm{mg} / \mathrm{kg} \mathrm{DM}$ & $4867 \pm 173$ & $4953 \pm 141$ & $2263 \pm 154$ & $3540 \pm 93$ & $8700-10200$ & - & \\
\hline $\mathrm{Al}$ & $\mathrm{mg} / \mathrm{kg} \mathrm{DM}$ & $10567 \pm 962$ & $12767 \pm 736$ & $7310 \pm 1435$ & $11167 \pm 728$ & & - & \\
\hline $\mathrm{Si}$ & $\mathrm{mg} / \mathrm{kg} \mathrm{DM}$ & $770 \pm 317$ & $977 \pm 105$ & $630 \pm 88$ & $507 \pm 133$ & & - & \\
\hline $\mathrm{P}$ & $\mathrm{mg} / \mathrm{kg} \mathrm{DM}$ & $1353 \pm 112$ & $1413 \pm 92$ & $637 \pm 52$ & $1080 \pm 97$ & & - & \\
\hline $\mathrm{K}$ & $\mathrm{mg} / \mathrm{kg} \mathrm{DM}$ & $2187 \pm 107$ & $2390 \pm 131$ & $1370 \pm 57$ & $2683 \pm 159$ & & - & \\
\hline $\mathrm{Ca}$ & $\mathrm{mg} / \mathrm{kg} \mathrm{DM}$ & $44067 \pm 3437$ & $47867 \pm 131$ & $23933 \pm 10178$ & $44500 \pm 9061$ & & - & \\
\hline $\mathrm{Ti}$ & $\mathrm{mg} / \mathrm{kg} \mathrm{DM}$ & $210 \pm 20$ & $223 \pm 17$ & $117 \pm 7$ & $217 \pm 17$ & & - & \\
\hline V & $\mathrm{mg} / \mathrm{kg} \mathrm{DM}$ & $27 \pm 8$ & $29 \pm 3$ & $15 \pm 3$ & $28 \pm 3$ & & - & \\
\hline $\mathrm{Cr}$ & $\mathrm{mg} / \mathrm{kg} \mathrm{DM}$ & $96 \pm 17$ & $107 \pm 7$ & $45 \pm 4$ & $76 \pm 0$ & $54-123$ & 300 & 300 \\
\hline $\mathrm{Mn}$ & $\mathrm{mg} / \mathrm{kg} \mathrm{DM}$ & $477 \pm 66$ & $510 \pm 11$ & $197 \pm 24$ & $323 \pm 29$ & $313-383$ & - & \\
\hline $\mathrm{Fe}$ & $\mathrm{mg} / \mathrm{kg} \mathrm{DM}$ & $48300 \pm 7355$ & $49867 \pm 3927$ & $19400 \pm 2012$ & $31633 \pm 1829$ & $29600-53900$ & - & \\
\hline Co & $\mathrm{mg} / \mathrm{kg} \mathrm{DM}$ & $13 \pm 1$ & $15 \pm 1$ & $5 \pm 0$ & $10 \pm 0$ & $6-8$ & 50 & 50 \\
\hline $\mathrm{Ni}$ & $\mathrm{mg} / \mathrm{kg} \mathrm{DM}$ & $74 \pm 1$ & $95 \pm 17$ & $41 \pm 7$ & $69 \pm 19$ & $29-44$ & 100 & 100 \\
\hline $\mathrm{Cu}$ & $\mathrm{mg} / \mathrm{kg} \mathrm{DM}$ & $770 \pm 663$ & $430 \pm 137$ & $133 \pm 7$ & $197 \pm 13$ & $191-362$ & 100 & 100 \\
\hline $\mathrm{Zn}$ & $\mathrm{mg} / \mathrm{kg} \mathrm{DM}$ & $1203 \pm 125$ & $1260 \pm 147$ & $567 \pm 36$ & $953 \pm 79$ & $1300-2000$ & 500 & 500 \\
\hline As & $\mathrm{mg} / \mathrm{kg} \mathrm{DM}$ & $12 \pm 1$ & $14 \pm 1$ & $<10$ & $12 \pm 1$ & $4-6$ & 50 & 50 \\
\hline $\mathrm{Se}$ & $\mathrm{mg} / \mathrm{kg} \mathrm{DM}$ & $<10$ & $<10$ & $<10$ & $<10$ & & - & \\
\hline $\mathrm{Sr}$ & $\mathrm{mg} / \mathrm{kg} \mathrm{DM}$ & $150 \pm 11$ & $167 \pm 7$ & $86 \pm 2$ & $153 \pm 7$ & $120-479$ & - & \\
\hline Mo & $\mathrm{mg} / \mathrm{kg} \mathrm{DM}$ & $9 \pm 3$ & $12 \pm 4$ & $3 \pm 0$ & $5 \pm 1$ & & - & \\
\hline $\mathrm{Pd}$ & $\mathrm{mg} / \mathrm{kg} \mathrm{DM}$ & $<1$ & $<1$ & $<1$ & $<1$ & & - & \\
\hline $\mathrm{Ag}$ & $\mathrm{mg} / \mathrm{kg} \mathrm{DM}$ & $5 \pm 2$ & $6 \pm 3$ & $2 \pm 1$ & $4 \pm 1$ & & - & \\
\hline Cd & $\mathrm{mg} / \mathbf{k g ~ D M}$ & $5 \pm 1$ & $7 \pm 1$ & $3 \pm 0$ & $5 \pm 1$ & 1 & 2 & 2 \\
\hline Sn & $\mathrm{mg} / \mathrm{kg} \mathrm{DM}$ & $220 \pm 60$ & $293 \pm 46$ & $106 \pm 13$ & $177 \pm 24$ & & - & \\
\hline $\mathrm{Sb}$ & $\mathrm{mg} / \mathrm{kg} \mathrm{DM}$ & $8 \pm 1$ & $12 \pm 2$ & $5 \pm 0$ & $8 \pm 2$ & & - & \\
\hline $\mathrm{Te}$ & $\mathrm{mg} / \mathrm{kg} \mathrm{DM}$ & $<2$ & $<2$ & $<2$ & $<2$ & & - & \\
\hline $\mathrm{Ba}$ & $\mathrm{mg} / \mathrm{kg} \mathrm{DM}$ & $663 \pm 68$ & $763 \pm 73$ & $350 \pm 49$ & $577 \pm 51$ & $246-420$ & - & \\
\hline W & $\mathrm{mg} / \mathrm{kg} \mathrm{DM}$ & $17 \pm 3$ & $16 \pm 2$ & $<1$ & $<1$ & & - & \\
\hline $\mathrm{Hg}$ & $\mathrm{mg} / \mathrm{kg} \mathrm{DM}$ & $6 \pm 0$ & $1 \pm 0$ & $<1$ & $2 \pm 0$ & & - & 1 \\
\hline $\mathrm{TI}$ & $\mathrm{mg} / \mathrm{kg} \mathrm{DM}$ & $<1$ & $<1$ & $<1$ & $<1$ & & - & \\
\hline $\mathrm{Pb}$ & $\mathrm{mg} / \mathrm{kg} \mathrm{DM}$ & $670 \pm 23$ & $1010 \pm 122$ & $460 \pm 57$ & $777 \pm 86$ & $128-477$ & 150 & 150 \\
\hline
\end{tabular}

case for TOC, hydrocarbon index and PAH, whereas PCB remained below limit values. Compared to ranges established by ÖNORM S 2122-2, the TOC/N ratio was rather high, although TOC was within established limits. Differences between legislations may be explained by the fact that in soils organic carbon is mainly present as humic substances which represent stable forms or carbon, whereas in organic wastes instable forms such as carbohydrates, proteins and lipids are present, which tend to form methane under anaerobic conditions in landfills. Ecological evaluation of use of the investigated samples as soil substitute, both degree of humification, i.e. the conversion of instable to stable organic substances in the material, and redox regime in the planned application should be considered.

\subsection{Leaching Behaviour}

Water soluble constituents are displayed in Table 5. These constituents were determined using a liquid: solid ratio of 5:1 over a $2 \mathrm{~h}$ period to compare soluble concentrations to recommended values for regular soil according to ÖNORM S 2122-2. However, limit values for landfilling and recycling relate to a liquid: solid ratio of 10 and leaching 
TABLE 3: Geogenic background concentrations of selected chemical elements (bdl: below detection limit).

\begin{tabular}{|c|c|c|c|c|c|c|c|c|c|c|c|c|c|c|}
\hline Parameter / Unit & $\mathrm{Ba}$ & $\mathrm{Ge}$ & Cd & $\mathrm{Cr}$ & Co & $\mathrm{Cu}$ & $\mathrm{Ga}$ & As & Hf & Sc & $\mathrm{Li}$ & $\mathrm{Au}$ & C & $\mathbf{S}$ \\
\hline Sample & ppm & ppm & ppm & ppm & ppm & ppm & ppm & ppm & ppm & ppm & ppm & ppm & wt.\% & wt. $\%$ \\
\hline 1 & 188 & bdl & bdl & 158 & 18 & 14 & bdl & 11 & bdl & 92 & 134 & 45 & 0.08 & 0.012 \\
\hline 2 & 367 & bdl & 2 & 67 & 13 & 14 & bdl & 9 & bdl & 34 & 128 & 39 & 1.15 & 0.027 \\
\hline 3 & 198 & bdl & bdl & 72 & 12 & 15 & bdl & 9 & bdl & 30 & 118 & 28 & 0.85 & 0.021 \\
\hline 4 & 377 & bdl & bdl & 143 & 13 & 14 & bdl & 7 & bdl & 33 & 128 & 32 & 0.82 & 0.020 \\
\hline 5 & 224 & bdl & bdl & 83 & 11 & 10 & bdl & 5 & bdl & 30 & 117 & 28 & 0.42 & 0.011 \\
\hline 6 & 194 & bdl & 2 & 84 & 12 & 9 & bdl & 8 & bdl & 29 & 115 & 29 & 0.32 & 0.016 \\
\hline
\end{tabular}

TABLE 4: Physical and chemical parameters of the investigated fine fractions $(n=3, s=1 \sigma)$, bold parameters are above threshold values, limit values for excavated soil landfills according to Federal Ministry for Agriculture, Forestry, Environment and Water Management (2008), for recycling quality class BA according to Federal Ministry for Sustainability and Tourism (2017).

\begin{tabular}{|c|c|c|c|c|c|c|c|c|}
\hline Parameter & Unit & $4.5-1.6 \mathrm{~mm}$ & $1.6-0.5 \mathrm{~mm}$ & $0.5-0.18 \mathrm{~mm}$ & $<0.18 \mathrm{~mm}$ & $\begin{array}{l}\text { Ranges } \\
\text { according } \\
\text { to ÖNORM } \\
\text { S2122-2 }\end{array}$ & $\begin{array}{l}\text { Limit value for } \\
\text { excavated soil } \\
\text { landfills }\end{array}$ & $\begin{array}{l}\text { Limit value } \\
\text { for recycling } \\
\text { (class BA) }\end{array}$ \\
\hline AOX & $\mathrm{mg} / \mathrm{kg} \mathrm{DM}$ & 255 & 285 & 218 & 293 & & & \\
\hline Cohesion number & 1 & 71.40 & 87.60 & 54.37 & 61.10 & $41-90$ & & \\
\hline Wet density & $\mathrm{g} / \mathrm{cm}^{3}$ & 0.72 & 0.74 & 1.09 & 0.95 & & & \\
\hline Dry density & $\mathrm{g} / \mathrm{cm}^{3}$ & 0.71 & 0.72 & 1.08 & 0.94 & & & \\
\hline TOC & $\%$ C DM & 8.31 & 8.04 & 7.91 & 7.72 & $1.5-11.6$ & 3.00 & 1.00 \\
\hline Total-N & $\% \mathrm{DM}$ & 0.49 & 0.53 & 0.27 & 0.34 & & & \\
\hline $\mathrm{C}$ & $\% \mathrm{DM}$ & 9.95 & 10.80 & 10.16 & 10.38 & & & \\
\hline TOC/N & 1 & 17.83 & 15.20 & 28.93 & 22.83 & $9-14$ & & \\
\hline $\begin{array}{l}\text { Hydrocarbon } \\
\text { index }\end{array}$ & $\mathrm{mg} / \mathrm{kg} \mathrm{DM}$ & 980 & 1,233 & 507 & 967 & & 200 & 200 \\
\hline РAH (16/EPA) & $\mathrm{mg} / \mathrm{kg} \mathrm{DM}$ & 17.80 & 17.73 & 6.38 & 7.68 & & 4 & 4 \\
\hline $\begin{array}{l}\text { Polychlorinated } \\
\text { biphenyles }\end{array}$ & $\mathrm{mg} / \mathrm{kg} \mathrm{DM}$ & 0.33 & 0.47 & $<0.10$ & 0.40 & & & 1 \\
\hline $\begin{array}{l}\text { Water content } \\
\quad\left(105^{\circ}\right)\end{array}$ & wt. $\%$ & 1.57 & 1.80 & 0.80 & 1.53 & & - & - \\
\hline
\end{tabular}

time of $24 \mathrm{~h}$. Thus, no direct comparison is possible. However, in order to assess the mobility of chemical elements, a comparison with all three groups of values provides some orientation.

Electric conductivity of the leachate was lowest for the fraction 0.5 to $0.18 \mathrm{~mm}$. This corresponds to the observation of the lowest solubility of this fraction in aqua regia, thus suggesting that the fraction is not only richer in silicates, but also in mineral phases which are soluble in aqua regia, but insoluble in water. In contrast to the observations made in aqua regia, for water extraction the finest fraction displayed a significantly higher percentage of soluble elements than other fractions. With the exception of fraction 0.5 to $0.18 \mathrm{~mm}$, a general trend of increasing solubility with decreasing particle size was detected, likely caused by an increased surface area.

Generally speaking, and in agreement with the findings of a previous study (Burlakovs et al., 2016), the share of water soluble contaminants was approx. three orders of magnitude lower than pseudo-total content. Chloride, sodium and potassium concentrations in leachate exceeded the range recommended for soils, thus implying a risk of salinization of the soil. In order to remove soluble salts from fine fractions, a washing process is suggested. Soluble nitrate and phosphate concentrations were also above recommended values for regular soil, displaying strong variations within one particle size range. Ammonium concentrations were found to be within the recommended range, suggesting that nitrification had taken place in the landfill due to microbiological activity. The high concentrations of nutrients may lead to eutrophication of the ground and surface waters in the vicinity of the potential application area. Thus, concentrations of these constituents should be decreased in the fine fractions $<4.5 \mathrm{~mm}$, e.g. by a washing process. Sulphate concentrations were above limit values for 10:1 leachates, although these cannot be directly applied.

Pseudo-total contents for nickel were below limit values, although with soluble concentrations above the recommended values for soils and in the range of the limit value for recycling of excavated soils. These values were in agreement with previous data (Burlakovs et al., 2016), implying that further treatment technologies should focus on immobilisation rather than on removal of Ni. For example, Rabelo Monich et al (2018) describe waste-derived glass ceramics obtained from plasma gasification of MSW with leachable concentrations of only 0.003 to $0.009 \mathrm{mg} / \mathrm{kg} \mathrm{DM}$, i.e. two 
TABLE 5: Soluble concentrations (liquid: solid ratio (L/S) 5:1, data refer to dry matter (DM)) of investigated fine fractions ( $\mathrm{n}=3$, $\mathrm{s}=1 \sigma)$, bold parameters are above threshold values, limit values for excavated soil landfills (L/S 10:1) according to Federal Ministry for Agriculture, Forestry, Environment and Water Management (2008), for recycling quality class BA (L/S 10:1) according to Federal Ministry for Sustainability and Tourism (2017), recommended values for normal soil according to Austrian Standards (2013).

\begin{tabular}{|c|c|c|c|c|c|c|c|c|}
\hline Parameter & Unit & $4.5-1.6 \mathrm{~mm}$ & $1.6-0.5 \mathrm{~mm}$ & $0.5-0.18 \mathrm{~mm}$ & $<0.18 \mathrm{~mm}$ & $\begin{array}{l}\text { Limit value for } \\
\text { excavated soil } \\
\text { landfills }\end{array}$ & $\begin{array}{l}\text { Limit value } \\
\text { for recycling } \\
\text { (class BA) }\end{array}$ & $\begin{array}{l}\text { Recommended } \\
\text { values for } \\
\text { normal soil }\end{array}$ \\
\hline $\mathrm{pH}$ & - & $7.65 \pm 0.08$ & $7.66 \pm 0.04$ & $7.81 \pm 0.04$ & $7.81 \pm 0.04$ & $6.5-11$ & $4.5-9.5$ & $5.5-8.8$ \\
\hline $\begin{array}{c}\text { Electric } \\
\text { conductivity }\end{array}$ & {$[\mathrm{mS} / \mathrm{m}]$} & $192 \pm 28$ & $226 \pm 38$ & $167 \pm 22$ & $290 \pm 14$ & 150 & 150 & - \\
\hline $\mathrm{NH}_{4}^{+}$ & [mg/kg DM] & $83 \pm 61$ & $61 \pm 4$ & $32 \pm 4$ & $70 \pm 8$ & 10 & 10 & $7.5-75$ \\
\hline $\mathrm{F}^{-}$ & [mg/kg DM] & $3.41 \pm 0.90$ & $3.43 \pm 1.11$ & $2.61 \pm 0.55$ & $3.22 \pm 0.90$ & 20 & 20 & \\
\hline $\mathrm{Cl}^{-}$ & [mg/kg DM] & $261 \pm 74$ & $310 \pm 95$ & $166 \pm 46$ & $327 \pm 84$ & - & - & $7.5-75$ \\
\hline $\mathrm{NO}_{3}^{-}$ & [mg/kg DM] & $287 \pm 379$ & $328 \pm 450$ & $165 \pm 208$ & $332 \pm 440$ & 443 & 443 & $37.5-150$ \\
\hline $\mathrm{PO}_{4}^{3-}$ & [mg/kg DM] & $10 \pm 6$ & $9 \pm 3$ & $5 \pm 2$ & $12 \pm 3$ & 15 & 15 & $0.1-2.25$ \\
\hline $\mathrm{SO}_{4}{ }^{2-}$ & [mg/kg DM] & $4297 \pm 833$ & $5700 \pm 1366$ & $4501 \pm 1132$ & $8834 \pm 190$ & & 2500 & \\
\hline TOC & [mg/kg DM] & $344 \pm 18$ & $416 \pm 28$ & $257 \pm 26$ & $471 \pm 20$ & 200 & 100 & $15-338$ \\
\hline B & [mg/kg DM] & $1.75 \pm 0.25$ & $2.00 \pm 0.28$ & $1.20 \pm 0.18$ & $1.90 \pm 0.19$ & - & - & $0.226-0.525$ \\
\hline $\mathrm{Na}$ & [mg/kg DM] & $224 \pm 33$ & $259 \pm 43$ & $139 \pm 20$ & $260 \pm 42$ & - & & $3-30$ \\
\hline $\mathrm{Mg}$ & [mg/kg DM] & $127 \pm 28$ & $163 \pm 41$ & $96 \pm 27$ & $186 \pm 31$ & - & & $7.5-45$ \\
\hline Al & [mg/kg DM] & $0.33 \pm 0.08$ & $0.42 \pm 0.06$ & $0.55 \pm 0.16$ & $0.45 \pm 0.06$ & - & - & $0.075-0.750$ \\
\hline $\mathrm{Si}$ & [mg/kg DM] & $6.45 \pm 0.24$ & $6.22 \pm 0.20$ & $3.35 \pm 0.30$ & $5.64 \pm 0.32$ & - & & $0.053-2.07$ \\
\hline $\mathrm{K}$ & [mg/kg DM] & $251 \pm 29$ & $281 \pm 31$ & $171 \pm 18$ & $306 \pm 33$ & - & & $15-75$ \\
\hline $\mathrm{Ca}$ & [mg/kg DM] & $1727 \pm 265$ & $2239 \pm 435$ & $1649 \pm 383$ & $3331 \pm 203$ & - & & 7.5-75 \\
\hline V & [mg/kg DM] & $<0.005$ & $<0.005$ & $<0.005$ & $<0.005$ & - & & $<0.045$ \\
\hline $\mathrm{Cr}$ & [mg/kg DM] & $0.01 \pm 0.00$ & $0.02 \pm 0.00$ & $0.01 \pm 0.00$ & $0.02 \pm 0.00$ & 1 & 0.5 & $<0.023$ \\
\hline $\mathrm{Mn}$ & [mg/kg DM] & $0.93 \pm 0.46$ & $1.23 \pm 0.65$ & $0.75 \pm 0.44$ & $1.42 \pm 0.55$ & & & $0.015-15$ \\
\hline $\mathrm{Fe}$ & [mg/kg DM] & $0.34 \pm 0.01$ & $0.35 \pm 0.03$ & $0.26 \pm 0.02$ & $0.39 \pm 0.04$ & & & $0.30-13.5$ \\
\hline Co & [mg/kg DM] & $0.03 \pm 0.01$ & $0.04 \pm 0.01$ & $0.02 \pm 0.01$ & $0.05 \pm 0.01$ & 1 & 1 & $0.002-0.075$ \\
\hline $\mathrm{Ni}$ & [mg/kg DM] & $0.34 \pm 0.18$ & $0.39 \pm 0.19$ & $0.23 \pm 0.09$ & $0.42 \pm 0.19$ & - & 0.4 & $<0.023$ \\
\hline $\mathrm{Cu}$ & [mg/kg DM] & $0.45 \pm 0.42$ & $0.47 \pm 0.44$ & $0.26 \pm 0.08$ & $0.51 \pm 0.48$ & & 2 & $0.023-0.90$ \\
\hline $\mathrm{Zn}$ & [mg/kg DM] & $0.30 \pm 0.08$ & $0.39 \pm 0.09$ & $0.23 \pm 0.06$ & $0.44 \pm 0.07$ & 20 & 4 & $0.03-0.75$ \\
\hline As & [mg/kg DM] & $<0.05$ & $0.06 \pm 0.00$ & $<0.05$ & $0.06 \pm 0.01$ & 0.5 & 0.5 & $<0.011$ \\
\hline $\mathrm{Se}$ & [mg/kg DM] & $<0.05$ & $<0.05$ & $<0.05$ & $<0.05$ & - & 0.1 & $0.008-0.038$ \\
\hline Mo & [mg/kg DM] & $0.10 \pm 0.03$ & $0.15 \pm 0.03$ & $0.10 \pm 0.03$ & $0.20 \pm 0.02$ & - & 0.5 & $0.023-0.375$ \\
\hline $\mathrm{Cd}$ & [mg/kg DM] & $<0.005$ & $0.005 \pm 0.00$ & $<0.005$ & $0.006 \pm 0.001$ & 0.05 & 0.05 & $<0.005$ \\
\hline Sn & [mg/kg DM] & $0.01 \pm 0.00$ & $0.01 \pm 0.00$ & $0.01 \pm 0.00$ & $0.01 \pm 0.00$ & 2 & 2 & $<0.008$ \\
\hline $\mathrm{Ba}$ & [mg/kg DM] & $0.35 \pm 0.03$ & $0.36 \pm 0.03$ & $0.33 \pm 0.03$ & $0.41 \pm 0.02$ & 10 & 10 & \\
\hline $\mathrm{Hg}$ & [mg/kg DM] & $<0.005$ & $<0.005$ & $<0.005$ & $<0.005$ & 0.01 & 0.01 & $<0.002$ \\
\hline $\mathrm{Tl}$ & [mg/kg DM] & $<0.005$ & $<0.005$ & $<0.005$ & $<0.005$ & & & $<0.002$ \\
\hline $\mathrm{Pb}$ & [mg/kg DM] & $0.01 \pm 0.00$ & $0.01 \pm 0.00$ & $<0.005$ & $0.01 \pm 0.00$ & 1 & 0.5 & $<0.075$ \\
\hline
\end{tabular}

orders of magnitude below the values obtained for fine fractions in this study. On the contrary, $\mathrm{Cu}, \mathrm{Pb}$, and $\mathrm{Zn}$, which far exceeded limit values for pseudo-total contents, were characterised by very low leaching in the range of recommended values for soils, thus indicating how use of a removal technology to decrease total content may be more appropriate.

To summarize, with regard to leaching behaviour, the release of soluble salts from the investigated materials is more problematic than release of heavy metals. The low leaching of heavy metals from ELFM fine fractions confirms previous data (Burlakovs et al., 2016).

\subsection{Mineralogical Analyses}

XRD analyses of each two samples of the finest particle size ranges $(0.5$ to $0.18 \mathrm{~mm}$ and $<0.18 \mathrm{~mm}$ ) indicate a composition of approx. 70 to 80 wt.\% quartz ( $\left.\mathrm{a}-\mathrm{SiO}_{2}\right), 10$ wt.\% calcite $\left(\mathrm{CaCO}_{3}\right), 10 \%$ feldspars and minor amounts of kaolinite $\left(\mathrm{Al}_{4}\left[(\mathrm{OH})_{8} \mid \mathrm{Si}_{4} \mathrm{O}_{10}\right]\right)$, illite $\left(\left(\mathrm{K}_{3} \mathrm{H}_{3} \mathrm{O}\right) \mathrm{Al}_{2}\left(\mathrm{Si}_{3} \mathrm{Al}\right)\right.$ $\mathrm{O}_{10}\left(\left(\mathrm{H}_{2} \mathrm{O}, \mathrm{OH}\right)_{2}\right)$, siderite $\left(\mathrm{FeCO}_{3}\right)$ and gypsum $\left(\mathrm{CaSO}_{4} \cdot 2 \mathrm{H}_{2} \mathrm{O}\right)$ with no significant differences between the two particle size ranges (Figure 7, Table 6). The two samples from the fraction 0.5 to $0.18 \mathrm{~mm}$ displayed more consistent differences between each other than to the finest particle size 
TABLE 6: Mineralogical composition of the particle size ranges 0.18 to $0.5 \mathrm{~mm}$ and $<0.18 \mathrm{~mm}$ from batches 1 and 2 (n.d.: not detected).

\begin{tabular}{|c|c|c|c|c|c|}
\hline Phase & Unit & B1_0.18-0.5 mm & B1_<0.18 mm & B2_0.18-0.5 mm & B2_ $<0.18 \mathrm{~mm}$ \\
\hline Quartz, $\mathrm{SiO}_{2}$ & wt.\% & 80 & 73 & 80 & 72 \\
\hline Calcite, $\mathrm{CaCO}_{3}$ & wt.\% & 6 & 10 & 10 & 13 \\
\hline Microcline, $\mathrm{KAISi}_{3} \mathrm{O}_{8}$ & wt. $\%$ & 12 & 4 & & n.d. \\
\hline Plagioclase, $\mathrm{NaxCa}_{1-x} \mathrm{Al}_{2-\mathrm{x}} \mathrm{Si}_{2+\mathrm{x}} \mathrm{O}_{8}$ & wt.\% & n.d. & 4 & n.d. & 3 \\
\hline Siderite, $\mathrm{FeCO}_{3}$ & wt. \% & 1 & 1 & 2 & 2 \\
\hline Kaolinite, $\mathrm{Al}_{4}\left[(\mathrm{OH})_{8} \mid \mathrm{Si}_{4} \mathrm{O}_{10}\right]$ & wt.\% & 1 & 1 & n.d. & 1 \\
\hline 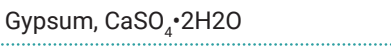 & wt.\% & 1 & 2 & n.d. & 3 \\
\hline Illite, $\left(\mathrm{K}, \mathrm{H}_{3} \mathrm{O}\right) \mathrm{Al}_{2}\left(\mathrm{Si}_{3} \mathrm{Al}\right) \mathrm{O}_{10}\left(\left(\mathrm{H}_{2} \mathrm{O}, \mathrm{OH}\right)_{2}\right.$ & wt. $\%$ & n.d. & 1 & 8 & 6 \\
\hline
\end{tabular}

range $<0.18 \mathrm{~mm}$. Thus, the hypothesis that the fraction 0.5 to $0.18 \mathrm{~mm}$ may be enriched in silicates could not be confirmed mineralogically.

Microprobe EDX analyses of sample B1_<0.18 mm (Figure 8 ) suggest that $\mathrm{Pb}$ is present in metallic form or as (hydr)oxide. Elemental distribution maps taken by WDX from the same area do not indicate oxygen in the respective area, indicating the presence of $\mathrm{Pb}$ in metallic form (Figure 9), also in agreement with the low leachability of $\mathrm{Pb}$ from the investigated sample. With respect to the potential utilization of the investigated sample as soil substitute, the risk of a release of significant amounts of $\mathrm{Pb}$ into ground water is very low, although a direct route from soil to (human) mouth cannot be excluded. It is indeed for this reason that technologies capable of removing $\mathrm{Pb}$-containing particles should be considered. The elemental map of $\mathrm{Pb}$ (Figure 9), in combination with the backscattered electron image (Figure 8), suggest that the dimensions of individual metallic lead grains are only a few $\mu \mathrm{m}$, although forming an agglomerate of approx. $100 \mu \mathrm{m}$ in size. These agglomerates might be separated from the other particles due to their different density ( $\mathrm{Pb}: 11.34 \mathrm{gcm}^{-3}$; quartz: $2.65 \mathrm{gcm}^{-3}$ ), e.g. by jigging or heavy-media separation.
Zinc is associated with S according to EDX analyses. WDX analyses revealed a complete absence of oxygen in the respective area, i.e. $\mathrm{Zn}$ is present as $\mathrm{ZnS}$, either as sphalerite ( $\mathrm{a}-\mathrm{ZnS}$ ) or wurtzite ( $\mathrm{B}-\mathrm{ZnS})$. The observed low leaching of $\mathrm{Zn}$ (Table 5 ) indicates a high stability of these phases under the experimental conditions. However, it should be taken into account that ZnS might be oxidized by atmospheric oxygen and water, which yields dissolved $\mathrm{Zn}$ and sulphuric acid, thus potentially posing a long-term risk when using the investigated sample as soil substitute. Removal of ZnS grains is highly challenging due to their grain size of few $\mu \mathrm{m}$ and, compared to $\mathrm{Pb}$, a less pronounced tendency to form agglomerates (Figure 8). Existing technologies to separate $\mathrm{ZnS}$ in this grain size, e.g. froth flotation (Peleka, Gallios, \& Matis, 2017), are too expensive for use in the production of a soil substitute. Hence, maintaining reducing conditions through addition of biochar may represent an interesting option for use in ensuring low levels of Zn leaching (Houben, Evrard, \& Sonnet, 2013).

$\mathrm{Ba}$ is associated with $\mathrm{S}$ according to EDX and also with $\mathrm{O}$ according to WDX, i.e. present as $\mathrm{BaSO}_{4}$, barite, which is characterized by a very low solubility (about $1.4 \mathrm{mg} / \mathrm{L}$

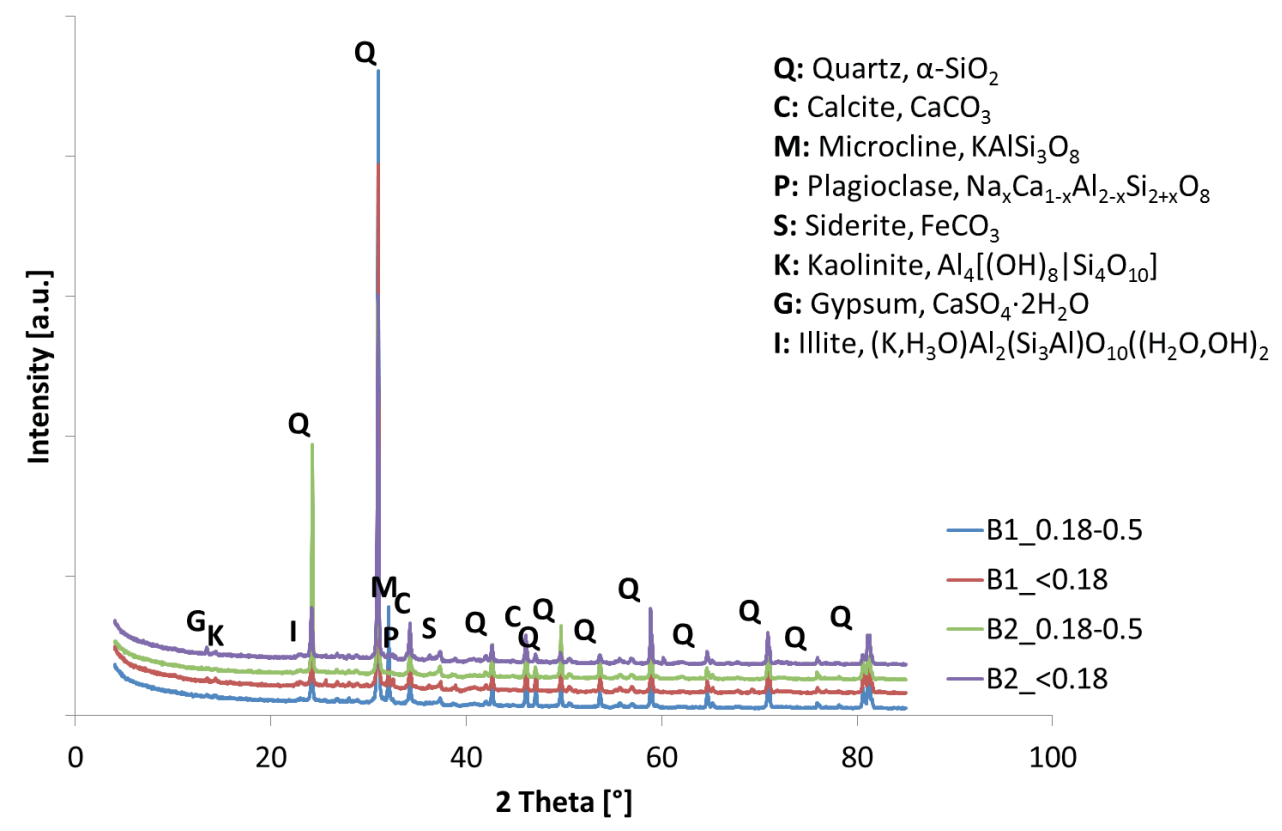

FIGURE 7: XRD patterns of the fine fractions 0.18 to $0.5 \mathrm{~mm}$ and $<0.18 \mathrm{~mm}$ from batches 1 and 2 . 
at $25^{\circ} \mathrm{C}$ (Blount, 1977)). This is in agreement with the observed low leaching of $\mathrm{Ba}$ (Table 5 ). In contrast to $\mathrm{Zn}$, which may be mobilized due to oxidation of sulphide, the same is not observed with $\mathrm{Ba}$, which occurs already as sulphate. Barite itself is not hazardous, thus the presence of $\mathrm{Ba}$ as barite does not pose an environmental risk when using the investigated sample as soil substitute.

$\mathrm{Cu}$ is diffusely distributed, which suggests its presence as an adsorbed species (Figure 9). The very low leaching of $\mathrm{Cu}$ from the investigated sample (Table 5) is in agreement with the slightly alkaline $\mathrm{pH}$ of the leachate which favours adsorption of cations, e.g. $\mathrm{Cu}^{2+}$, on the surfaces of minerals and organic matter. However, to avoid oral ingestion, e.g. by children, and ensure compliance with the threshold value for pseudo-total content of $\mathrm{Cu}$, this element should be removed from the material prior to utilization as soil substitute. To desorb Cu from the surfaces, they will need to be charged positively, which can be done by acid washing and may prove to be an interesting option to condition the material for use as soil substitute.

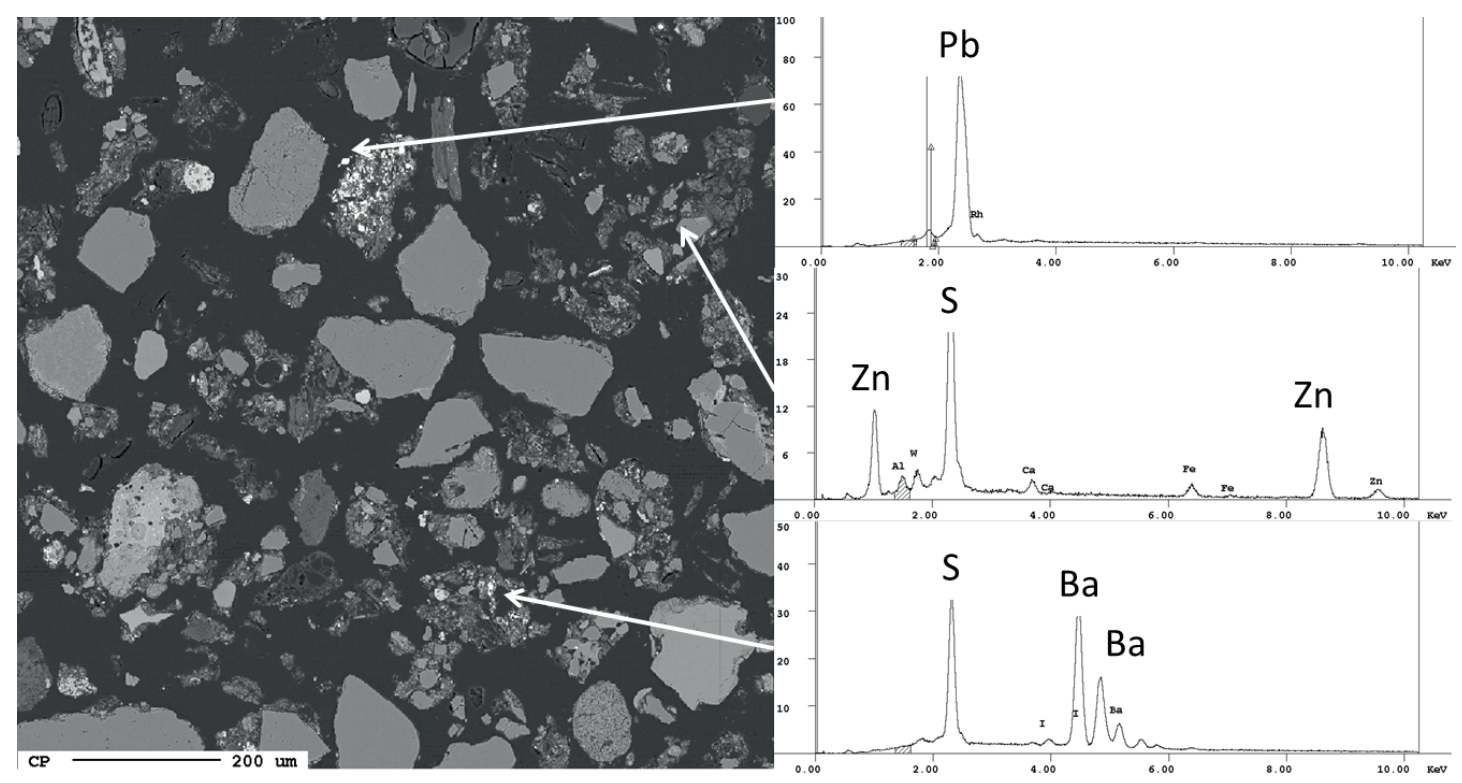

FIGURE 8: Backscattered electron image (left) and EDX spot analyses of heavy metal bearing phases in sample B1_<0.18 mm.
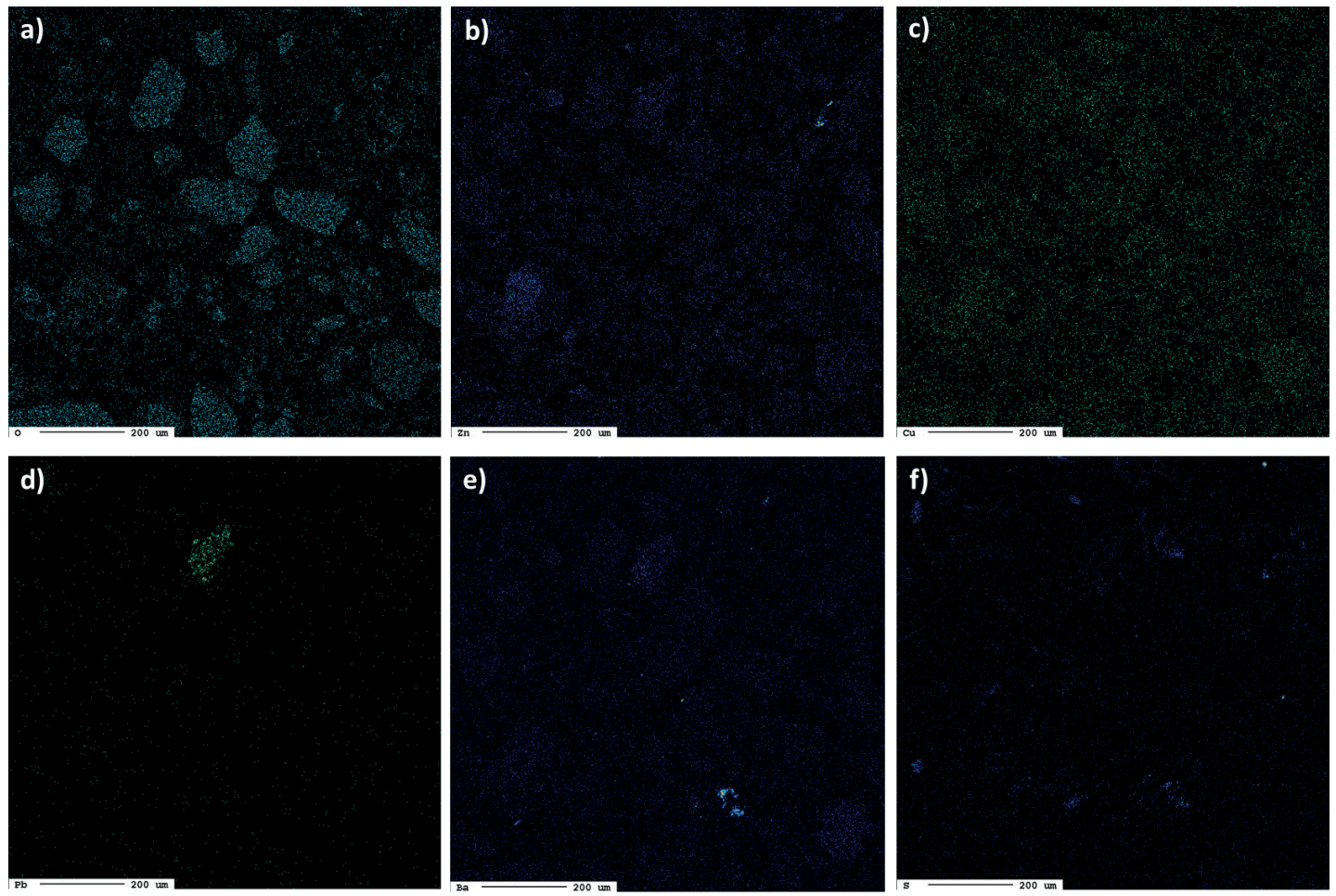

FIGURE 9: Elemental mapping of (a) oxygen, (b) Zn, (c) Cu, (d) Pb, (e) Ba, and (f) $\mathrm{S}$ in sample B1_<0.18 mm. 
In sample B1_0.18-0.5 mm, $\mathrm{Zn}$ is associated with $\mathrm{Fe}$, but not with $S$ according to EDX analyses (Figure 10). WDX mappings indicate that no $\mathrm{O}$ is present in this grain, i.e. $\mathrm{Zn}$ is present as Fe-Zn alloy. However, it should be noted how only one Zn-containing grain was found in both B1_<0.18 $\mathrm{mm}$ and B1_0.18-0.5 mm, thus preventing any firm assumptions from being made with regard to $Z n$-containing phases in the particle size ranges. However, $Z n$ leaching of this sample is similarly low in all fractions and both Fe-Zn alloys and ZnS are characterized by a low solubility. In both samples, $\mathrm{Zn}$-containing grains are in the range of a few $\mu \mathrm{m}$. With respect to separation of $Z n$, presence of the latter in Fe-Zn alloys would enhance the use of additional technologies such as jigging or heavy-media separation, which cannot be used for ZnS.

EDX spectra of individual particles (Figure 10) and WDX elemental distribution maps (Figure 11) confirm the presence of $\mathrm{Ba}$ as barite and the diffuse distribution of $\mathrm{Cu}$.

In contrast to sample B1_<0.18 mm no Pb could be detected in sample B1_0.18-0.5 mm.

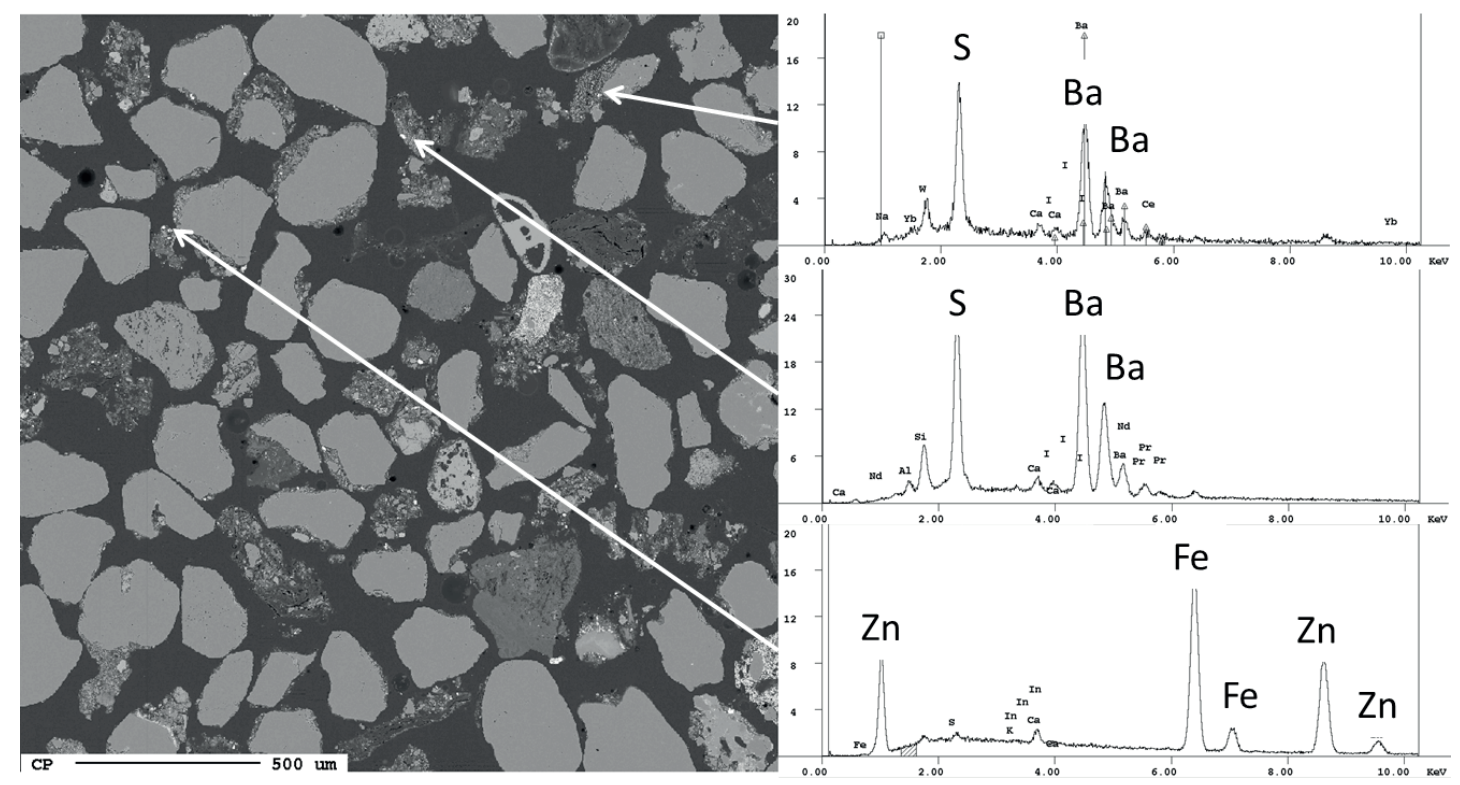

FIGURE 10: Backscattered electron image (left) and EDX spot analyses of heavy metal bearing phases in sample B1_0.18-0.5 mm.

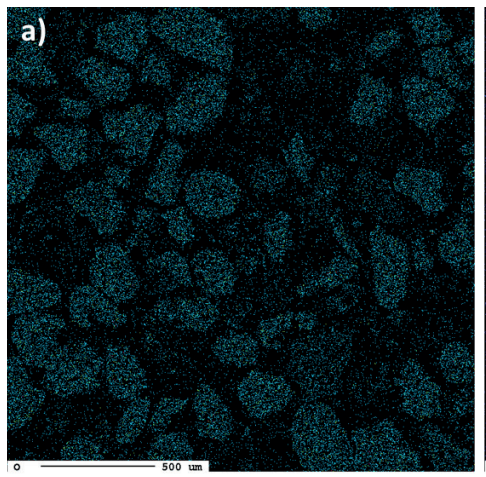

d)

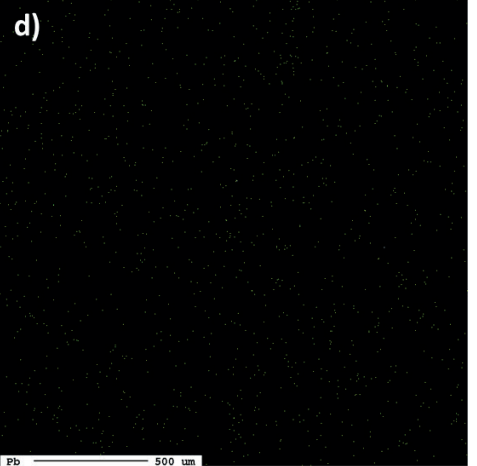

b)

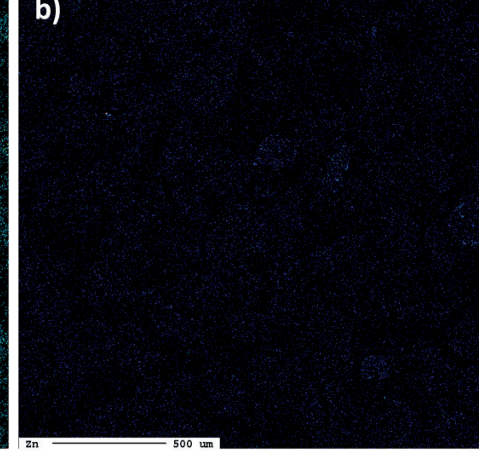

e)

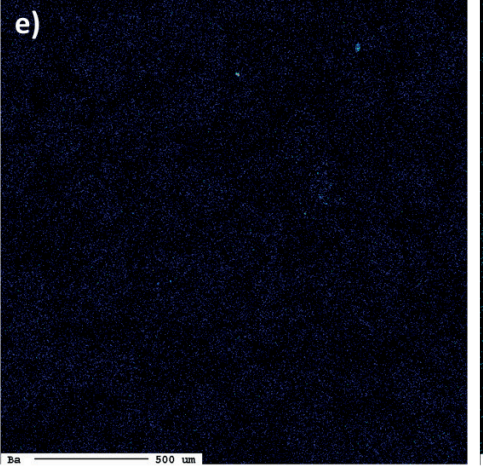

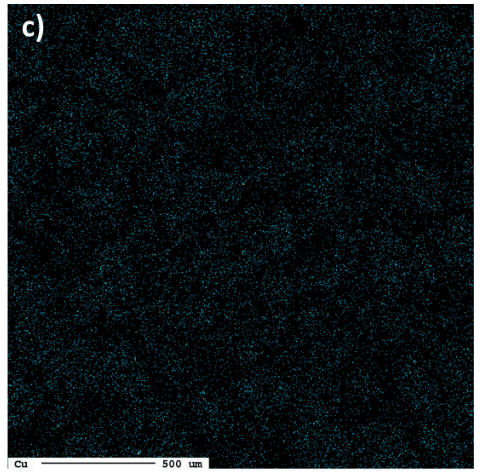

f)

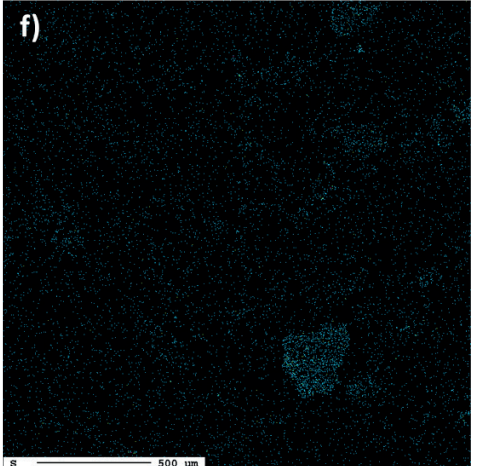

FIGURE 11: Elemental mapping of (a) oxygen, (b) Zn, (c) Cu, (d) Pb, (e) Ba, and (f) S in sample B1_0.18-0.5 mm. 
In sample B2-8_<0.18 mm, EDX analyses (Figure 12) indicated the presence of monazite, $(\mathrm{La}, \mathrm{Ce}, \mathrm{Nd})\left[\mathrm{PO}_{4}\right]$, the most important ore mineral for rare earth elements (REE). Cerium, $\mathrm{Nd}$ and La have been reported in MSW landfills in the range of $14-25 \mathrm{mg} / \mathrm{kg}, 8-12 \mathrm{mg} / \mathrm{kg}$ and $7-11 \mathrm{mg} / \mathrm{kg}$, respectively (Gutiérrez-Gutiérrez et al., 2015), which is below the average concentrations in the continental crust (Taylor, 1964) and of no economic or ecological relevance. However, the mineralogical bonding of REE in MSW landfills has not to date been investigated. EDX analyses clearly indi- cate that Thorium (Th) is incorporated in the investigated monazite grain, thus causing environmental concern due to its radioactivity. Considering that this grain with a size of few $\mu \mathrm{m}$ is the only one in the entire investigated sample, the environmental impact is negligible.

As in sample B1-8_<0.18 mm, EDX analysis shows the association of $\mathrm{Zn}$ with S (Figure 12) and WDX elemental mapping (Figure 13) indicates the absence of $O$ in this grain, meaning that $\mathrm{Zn}$ is present as zinc sulphate. As hydrogen cannot be measured, it remains unclear if the wa-

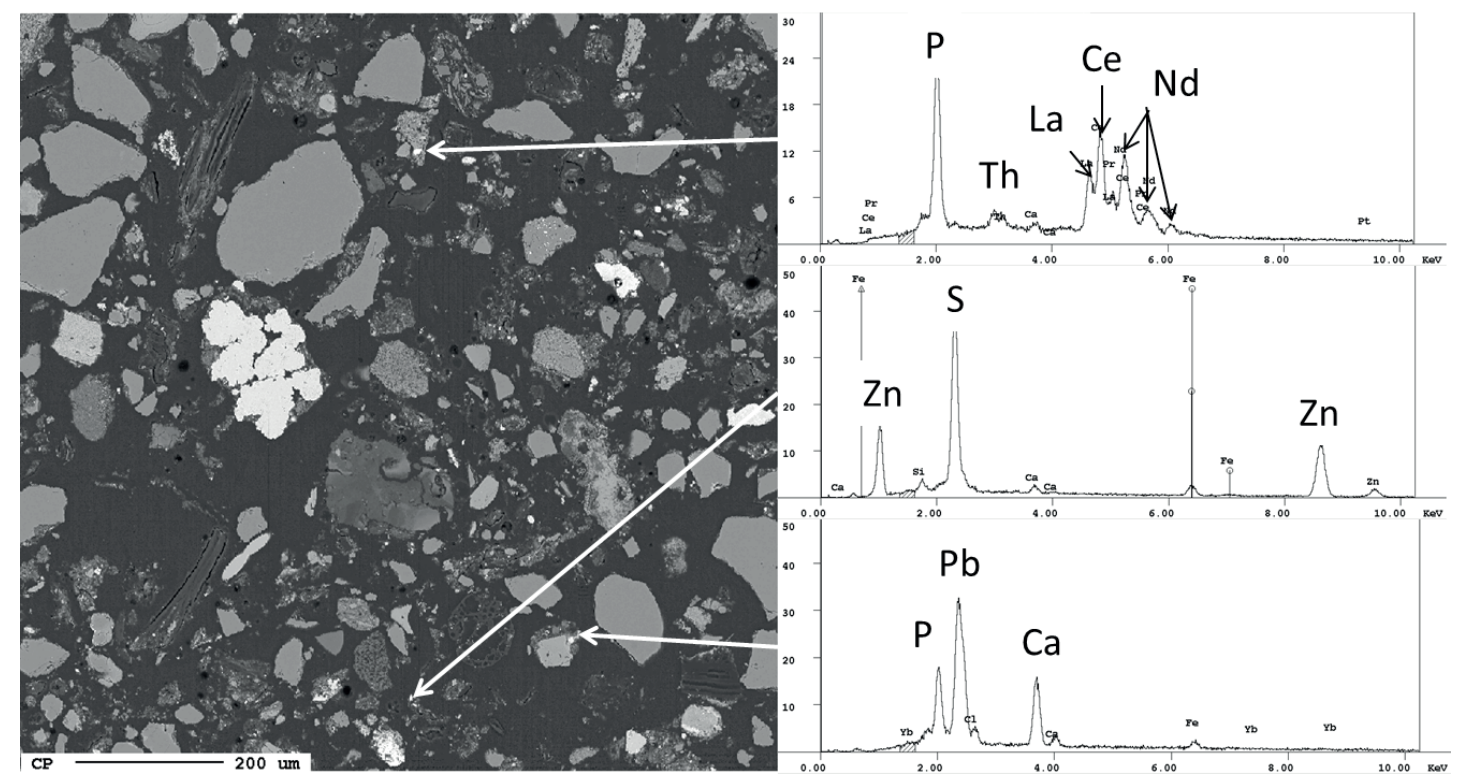

FIGURE 12: Backscattered electron image (left) and EDX spot analyses of heavy metal bearing phases in sample B2_<0.18 mm.
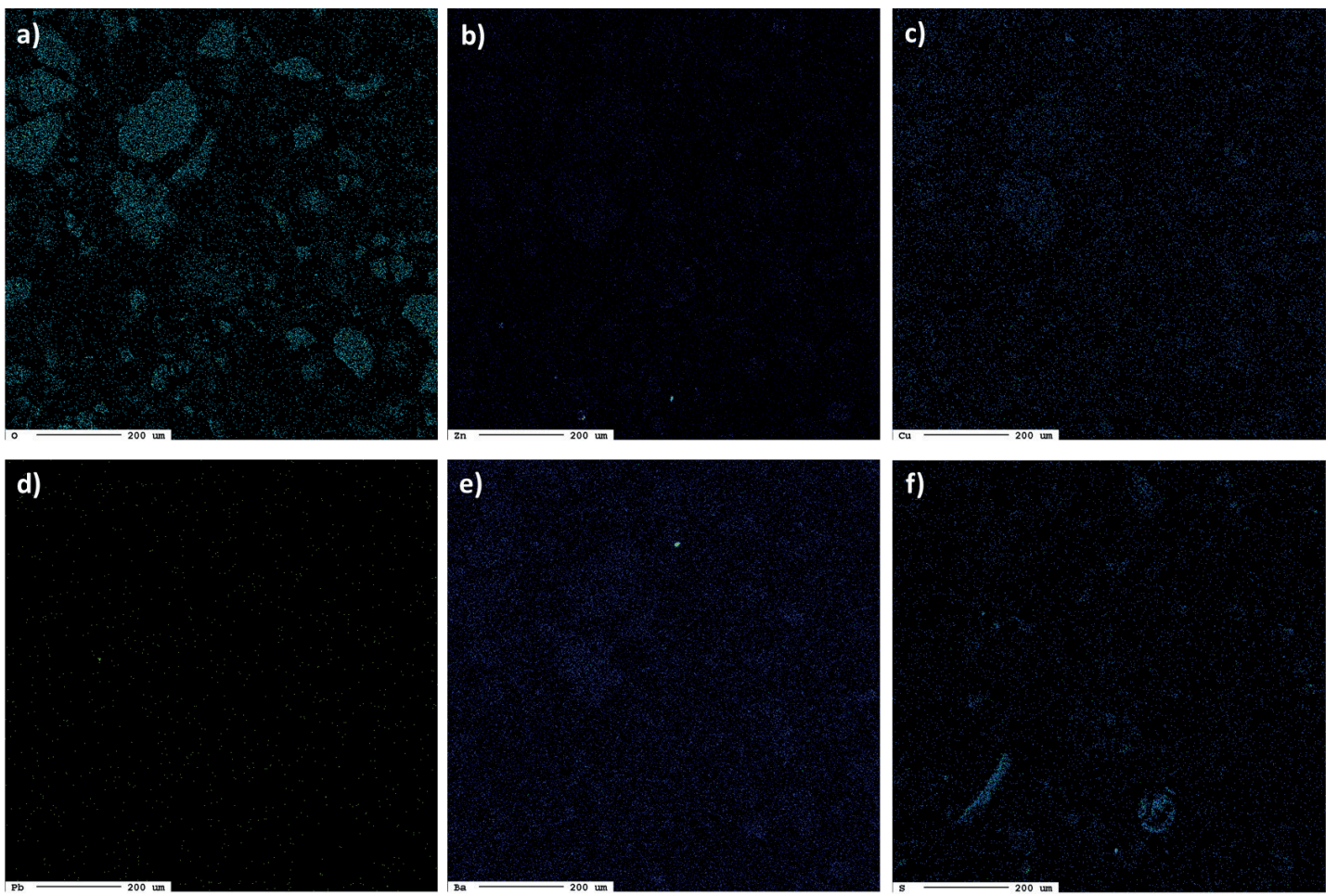

FIGURE 13: Elemental mapping of (a) oxygen, (b) $\mathrm{Zn}$, (c) $\mathrm{Cu}$, (d) $\mathrm{Pb}$, (e) Ba and (f) $\mathrm{S}$ in sample B2_<0.18 mm. 
ter-free zincosite $\left(\mathrm{ZnSO}_{4}\right)$ or the water-containing phases gunningite $\left(\mathrm{ZnSO}_{4} \cdot \mathrm{H}_{2} \mathrm{O}_{2}\right)$, boyleite $\left(\mathrm{ZnSO}_{4} \cdot 4 \mathrm{H}_{2} \mathrm{O}_{2}\right)$, goslarite or zinc melanterite (both $\mathrm{ZnSO}_{4} \cdot 7 \mathrm{H}_{2} \mathrm{O}_{2}$ ) are present. It is suggested that more oxidizing conditions were present in this sample compared to the other two samples, where Zn was present as ZnS. However, as leaching does not significantly differ between the samples, the difference in mineralogy does not seem to produce a significant impact on environmental performance. EDX pattern indicates the presence of a calcium lead phosphate (Figure 12), although
WDX mappings suggest the absence of $\mathrm{Pb}$. As in the other samples, WDX mappings indicate the diffuse distribution of $\mathrm{Cu}$ within the sample.

In sample B2_0.18-0.5 mm, EDX analyses confirmed the association of $\mathrm{Zn}$ and $\mathrm{S}$ (Figure 14). In contrast to the other samples, this phase is not present as individual grain, but forms a rim around a quartz grain. WDX mapping of 0 (Figure 15) also reveals the presence of oxygen in this rim, i.e. $\mathrm{Zn}$ is present as $\mathrm{ZnSO}_{4}$ as in sample $\mathrm{B} 2-8_{-}<0.18 \mathrm{~mm}$. EDX patterns also confirmed the presence of $\mathrm{Ba}$ as barite,

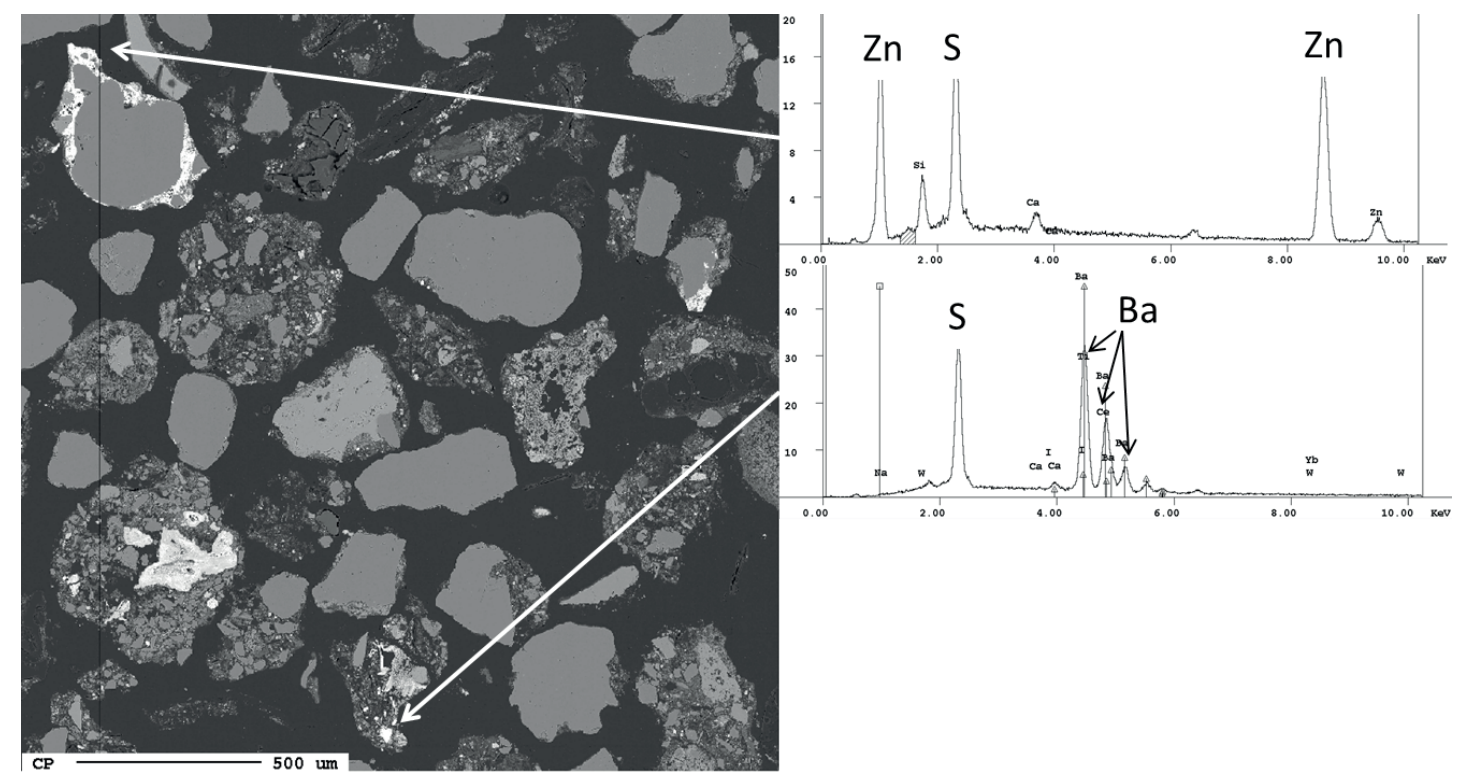

FIGURE 14: Backscattered electron image (left) and EDX spot analyses of heavy metal bearing phases in sample B2_0.18-0.5 mm.
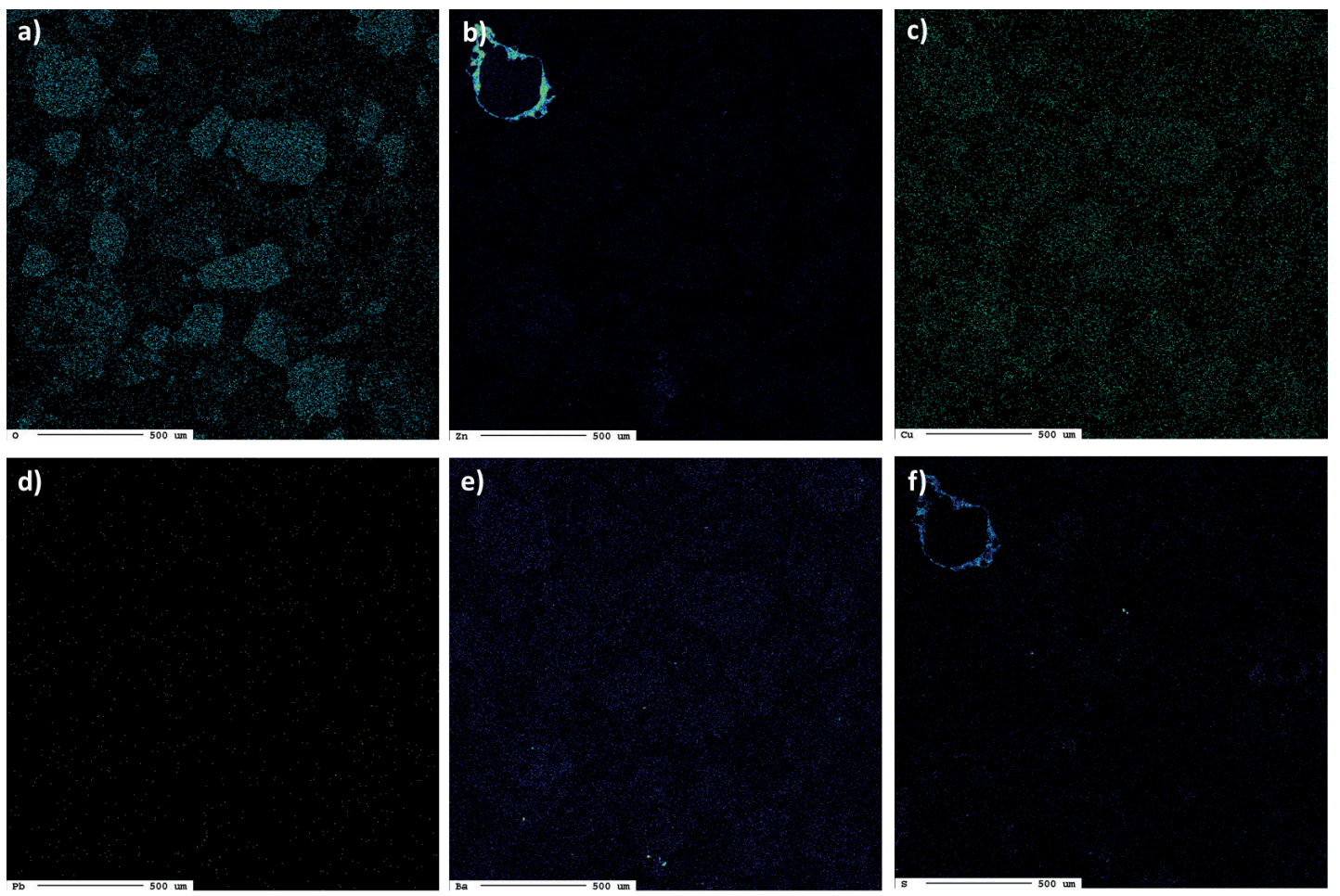

FIGURE 15: Elemental mapping of (a) oxygen, (b) Zn, (c) Cu, (d) Pb, (e) Ba and (f) S in sample B2_0.18-0.5 mm. 
$\mathrm{BaSO}_{4} . \mathrm{Pb}$ could not be detected in this sample, whereas $\mathrm{Cu}$ is randomly distributed in the same way as in other samples (Figure 15).

To summarize, mineralogical investigations confirm the presence of $\mathrm{Pb}$ as metal and as $\mathrm{Pb}-\mathrm{Ca}$ phosphate, $\mathrm{Zn}$ as Fe- $\mathrm{Zn}$ alloy, sulphide and sulphate, $\mathrm{Ba}$ as barite, $\mathrm{Cu}$ adsorbed to mineral surfaces and REE as monazite. This stable incorporation (and in case of $\mathrm{Cu}$, adsorption) explains the low leaching of heavy metals from the investigated samples. However, the mineralogical bonding of $\mathrm{Ni}$, characterised by rather high leaching, is in agreement with observations from natural rocks (Vollprecht et al., 2019).

\section{CONCLUSIONS}

Fine fractions are a major obstacle for the economic feasibility of (E)LFM. Although screening and density separation may be used to recover significant amounts of combustible and inert materials, the fine-grained soil-like materials remain an important challenge.

In this study, we refute our first working hypothesis according to which screening in the range $<4.5 \mathrm{~mm}$ allows for a separation into a clean coarser fraction and a contaminated finer fraction. Conversely, we confirmed our second working hypothesis, i.e. that the mineralogy of ELFM fine fractions is related to their leachability, as several host phases for low-leaching elements such as a Fe-Zn alloy, $\mathrm{ZnS}$ and $\mathrm{ZnSO}_{4}$, metallic $\mathrm{Pb}$ and $\mathrm{Pb}-\mathrm{Ca}$ phosphate, were identified.

Briefly, the main problematic factors in the recycling of ELFM fine fractions are represented by the high pseudo-total contents of organic carbon and heavy metals, in the present case study $\mathrm{Cu}, \mathrm{Zn}, \mathrm{Cd}, \mathrm{Hg}$ and $\mathrm{Pb}$, which hinder use of these fractions in countries in which limit values for pseudo-total contents have been established in environmental legislation. In countries regulating only the leachable contents of heavy metals, the utilization of fine fractions from (E)LFM seems more realistic, as this study shows that the majority of heavy metals is tightly bound in low-soluble mineral phases or strongly adsorbed to mineral surfaces.

A remaining challenge in the present case study is the rather high leaching of $\mathrm{Ni}$, which may be encountered when using immobilization technologies. Further research is needed to investigate both the adverse effects of carbon speciation, such as methane formation, and beneficial effects including carbon sequestration in stable humic substances.

In a broader scope, future research on fine fractions from ELFM should be conducted to investigate alternative uses, e.g. as landfill liner (Liebetegger 2015) or other consituent in an "aftercare-free landfill". For this purpose, a low hydraulic conductivity and low leaching of heavy metals might be sufficient, particularly as the material would continue to be considered a waste, with no need to meet end-of-waste criteria need. Therefore, an intelligent use of the fine fractions to minimize aftercare needs seems to represent the most promising option. A saving on aftercare costs and consideration of the real estate/ecosystem services (Burlakovs et al., 2017) may provide new pathways for future ELFM projects and should be investigated.

\section{ACKNOWLEDGEMENTS}

This research was funded by the European Union Horizon 2020 research and innovation programme under the Marie Skłodowska-Curie grant agreement No. 721185 "NEW-MINE" (EU Training Network for Resource Recovery through Enhanced Landfill Mining; www.new-mine.eu). The authors thank Alexia Aldrian for chemical and Federica Zaccarini and Maik Zimmermann for electron microprobe analyses.

\section{REFERENCES}

Austrian Standards, 2013. ÖNORM S2122-2. Soils from waste - Part 2: Evaluation on the basis of fractional analyses.

Bhatnagar, A., Kaczala, F., Burlakovs, J., Kriipsalu, M., Hogland, M., Hogland, W., 2017. Hunting for valuables from landfills and assessing their market opportunities. A case study with Kudjape landfill in Estonia. Waste Manag. Res. 35(6), 627-635.

Blount, C., 1977. Barite solubilities and thermodynamic quantities up to $300^{\prime} \mathrm{C}$ and 1400 bar. Am. Min. 62, 942-957.

Burlakovs, J., Jani, Y., Kriipsalu, M., Vincevica-Gaile, ZH., Kaczala, F., Celma, G., Ozola, R., Rozina, L., Rudovica, V., Hogland, M., Viksna, A., Pehme, K.-M., Hogland, W., Klavins, M. 2018. On the way to 'zero waste' management: Recovery potential of elements, including rare earth elements, from fine fraction of waste. J. Clean. Prod. $186,91-90$.

Burlakovs, J., Kriipsalu, M., Klavins, M., Bhatnagar, A., 2017. Paradigms on landfill mining: From dump site scavenging to ecosystem services revitalization. Resour. Conserv. Recy., 123, 73-84-.

Burlakovs, J., Kaczala, F., Vincevica-Gaile, Z., Rudovica, V., Orupöld, K., Stapkevica, M., Bhatnagar, A., Kriipsalu, M., Hogland, M., Klavins, M., Hogland, W., 2016. Mobility of Metals and Valorization of Sorted Fine Fractions of Waste After Landfill Excavation. Waste Biomass Valori. 7(3), 593-602.

Federal Ministry for Agriculture, Forestry, Environment and Water Management, 2008. Landfill Ordincance. https://www.ris.bka.gv.at/ GeltendeFassung.wxe?Abfrage=Bundesnormen\&Gesetzesnummer $=20005653$

Federal Ministry for Sustainability and Tourism, 2017. Federal Waste Management Plan.

Frändegård, P., Krook, J., Svensson, N., 2015. Integrating remediation and resouce recovery: On the economic conditions of landfill mining. Waste Manag. 42, 137-147.

García López, C., Ni, A., Hernández Parrodi, J., Küppers, B., Raulf, K., Pretz, T., 2019. Characterization of landfill mining material after ballistic separation to evaluate material and energy recovery potential. Detritus 8, 5-23.

Greedy, D., 2016. Landfilling and landfill mining. Waste Manag. Res. 34(1), 1-2.

Gutiérrez-Gutiérrez, S., Coulon, F., Jiang, Y., Wagland, S., 2015. Rare earth elements and critical metal content of extracted landfilled material and potential recovery opportunities. Waste Manag. 42, 128-136.

Hernández Parrodi, J. C., García López, C., Küppers, B., Raulf, K., Vollprecht, D., Pretz, T., Pomberger, R., 2019a. Case study on enhanced landfill mining at Mont-Saint-Guibert landfill in Belgium: Characterization and potential of fine fractions. Detritus 8, 47-61.

Hernández Parrodi, J. C., Höllen, D., Pomberger, R., 2018a. Characterization of fine fractions from landfill mining: A review of previous investigations. Detritus 2, 46-62.

Hernández Parrodi, J. C., Höllen, D., Pomberger, R., 2018b. Potential and main technological challenges for material and energy recovery from fine fractions of landfill mining: A critical review. Detritus 3, 19-29.

Hernández Parrodi, J. C., Lucas, H., Gigantino, M., Sauve, G., Esguerra, J. L., Einhäupl, P, Vollprecht, D., Pomberger, R., Friedrich, B., Van Acker, K., Krook, J., Svensson, N., Van Passel, S., 2019b. Integration of resource recovery into current waste management through (enhanced) landfill mining. Detritus 8, 141-156.

Hernández Parrodi, J. C., Raulf, K., Vollprecht, D., Pretz, T., Pomberger, R., 2019c. Case study on enhanced landfill mining at Mont-SaintGuibert landfill in Belgium: Mechanical processing of fine fractions for material and energy recovery. Detritus 8, 62-78. 
Hogland, W. H., 2010. Enhanced Landfill Mining - Material recovery, energy utilisation and economics in the EU (Directive) perspective. Proceedings of the 1st International Academic Symposium on Enhanced Landfill Mining, 4-6.

Houben, D., Evrard, L., Sonnet, P., 2013. Mobility, bioavailability and $\mathrm{pH}$-dependent leaching of cadmium, zinc and lead in a contaminated soil amended with biochar. Chemosphere 92(11), 1450-1457.

Jani, Y., Kaczala, F., Marchand, C., Hogland, M., Kriipsalu, M., Hogland, W., Kihl, A., 2016. Characterisation of excavated fine fraction and waste composition from a Swedish landfill. Waste Manag. Res. 34(12), 1292-1299.

Kelly, E. \& Spottiswood, D., 1989. The theory of electrostatic separations: A review Part I. Fundamentals. Miner. Eng. 2(1), 33-46.

Krook, J., Svensson, N., Eklund, M., 2012. Landfill mining: A critical review of two decades of research. Waste Manag. 32(3), 513-520.

Küppers, B., Hernández Parrodi, J. C., García López, C., Pomberger, R., Vollprecht, D., 2019. Potential of sensor-based sorting in enhanced landfill mining. Detritus 8, 24-30.

Lane, D., Cook, N., Grano, S., Ehrig, K., 2016. Selective leaching of penalty elements from copper concentrates: A review. Miner. Eng. 98, 110-121.

Laner, D., Esguerra, J.L., Krook, J., Horttanainen, M., Kriipsalu, M., Rosendal, R.M., Stansiavljević, 2019. Systematic assessment of critical factors for the economic performance of landfill mining in Europe: What drives the economy of landfll mining. Waste Manag., 95, 674-686.

Liebetegger, W., 2015. Landfill Mining - Charakterisierung der Fein- und heizwertreichen Fraktion. Master Thesis. Montanuniversität Leoben.

Lucas, H., García López, C., Hernández Parrodi, J. C., Vollprecht, D., Raulf, K., Pomberger, R., Pretz, T., Friedrich, B., 2019. Quality assessment of non-ferrous metals in landfill mining: A case study in Belgium. Detritus 8, 79-90.

Mönkäre, T. J., Palmroth, M. R., Rintala, J. A., 2016. Characterization of fine fraction mined from two Finnish landfills. Waste Manag. 47A, 34-39.
Neuhold, S., van Zomeren, A., Dijkstra, J.J., van der Sloot, H.A., Drissen, P., Algermissen, D., Mudersbach, D., Schüler, S., Griessacher, T., Raith, J., Pomberger, R., Vollprecht, D., 2019. Investigation of Possible Leaching Control Mechanisms for Chromium and Vanadium in Electric Arc Furnace (EAF) Slags Using Combined Experimental and Modeling Approaches. Minerals 9, 525.

Peleka, E., Gallios, G., Matis, K., 2017. A perspective on flotation: a review. J. Chem. Technol. Biotechnol. 93, 615-623.

Quaghebeur, M., Laenen, B., Geysen, D., Nielsen, P., Pontikes, Y., van Gerven, T., Spooren, J., 2013. Characterization of landfilled materials: screening of the enhanced landfill mining potential. J. Clean. Prod. $55,72-83$.

Rabelo Monich, P., Rincón Romero, A., Höllen, D., Bernardo, E., 2018. Porous glass-ceramics from alkali activation and sinter-crystallization of mixtures of waste glass and residues from plasma processing of municipal solid waste. J. Clean. Prod. 188, 871-878.

Republic of Austria, 2002. Bundesgesetz über eine nachhaltige Abfallwirtschaft (Abfallwirtschaftsgesetz 2002 - AWG 2002). BGBI. I Nr. 102/2002.

Savage, G.M., Golueke, C.G., von Stein, E.L., 1993. Landfill mining: past and present. Biocycle 34, 58-61.

Scalenghe, R. \& Marsan, F., 2009. The anthropogenic sealing of soils in urban areas. Landscape Urban Plan. 90(1-2), 1-10.

Scheffer, F. \& Schachtschabel, P., 2018. Lehrbuch der Bodenkunde (17th Edition). Springer Spektrum.

Spooren, J., van den Bergh, K., Nielsen, P., Quaghebeur, M., 2013. Landfilled fine grained mixed industrial waste: Metal recovery. Acta Metall. Slovaca 19(3), 160-169.

Taylor, S., 1964. Abundance of chemical elements in the continental crust: a new table. Geochim. Cosmochim. Acta 28(8), 1,273-1,285.

Vollprecht, D., Berger, M., Altenburger-Junker, I., Neuhold, S., Sedlazeck, K. P., Aldrian, A., Dijkstra, J.J., van Zomeren, A., Raith, J., 2019. Mineralogy and Leachability of Natural Rocks-A Comparison to Electric Arc Furnace Slags. Minerals 9, 501.

Wanka, S., Münnich, K., Fricke, K., 2017. Landfill Mining - Wet mechanical treatment of fine MSW with a wet jigger. Waste Manage. 59, 316-323. 